Bryn Mawr College

Scholarship, Research, and Creative Work at Bryn Mawr College

Classical and Near Eastern Archaeology Faculty

Research and Scholarship

Classical and Near Eastern Archaeology

1999

\title{
Tearing Apart the Zagreus Myth: A Few Disparaging Remarks on Orphism and Original Sin
}

Radcliffe G. Edmonds III

Bryn Mawr College, redmonds@brynmawr.edu

Let us know how access to this document benefits you.

Follow this and additional works at: http://repository.brynmawr.edu/arch_pubs

Part of the Classical Archaeology and Art History Commons, and the History of Art, Architecture, and Archaeology Commons

\section{Citation}

Edmonds, Radcliffe G. III, "Tearing Apart the Zagreus Myth: A Few Disparaging Remarks on Orphism and Original Sin" (1999). Classical and Near Eastern Archaeology Faculty Research and Scholarship. Paper 112.

http://repository.brynmawr.edu/arch_pubs/112

This paper is posted at Scholarship, Research, and Creative Work at Bryn Mawr College. http://repository.brynmawr.edu/arch_pubs/112

For more information, please contact repository@brynmawr.edu. 
Tearing Apart the Zagreus Myth: A Few Disparaging Remarks on Orphism and Original Sin Author(s): Radcliffe Edmonds

Reviewed work(s):

Source: Classical Antiquity, Vol. 18, No. 1 (Apr., 1999), pp. 35-73

Published by: University of California Press

Stable URL: http://www.jstor.org/stable/2501 1092

Accessed: $2 7 \longdiv { / 0 1 / 2 0 1 2 ~ 1 3 : 2 1 }$

Your use of the JSTOR archive indicates your acceptance of the Terms \& Conditions of Use, available at http://www.jstor.org/page/info/about/policies/terms.jsp

JSTOR is a not-for-profit service that helps scholars, researchers, and students discover, use, and build upon a wide range of content in a trusted digital archive. We use information technology and tools to increase productivity and facilitate new forms of scholarship. For more information about JSTOR, please contact support@jstor.org. 


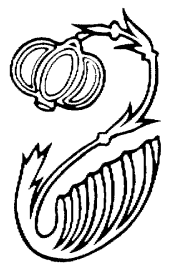

\title{
Tearing Apart the Zagreus Myth: A Few Disparaging Remarks On Orphism and Original Sin
}

\begin{abstract}
Pure I come from the pure, Queen of those below the earth, and Eukles and Eubouleus and the other gods and daimons; For I boast that I am of your blessed race. I have paid the penalty on account of deeds not just; Either Fate mastered me or the Thunderer, striking with his lightning. Now I come, a suppliant, to holy Phersephoneia, that she, gracious, may send me to the seats of the blessed. ${ }^{1}$
\end{abstract}

So proclaims the deceased woman of Thurii on the gold tablet buried in her tomb in Timpone Piccolo. This enigmatic statement, similar to the proclamations on the gold tablets found in the other two tombs in the mound, has piqued the interest of scholars ever since its discovery in 1879. Despite the protests of Wilamowitz, Linforth, Zuntz, and, most recently, Luc Brisson, scholars continue, for the most part, to interpret these tablets in terms of what is known as the Orphic myth of Zagreus. This tale, called "the cardinal myth of Orphism," is typically related as it is in Morford and Lenardon's introductory textbook on Greek Mythology (sixth edition, 1999):

I would like to thank Chris Faraone, Hans Dieter Betz, J. Z. Smith, Bruce Lincoln, Fritz Graf, and the editors and readers at Classical Antiquity for their comments on earlier drafts of this paper. It need scarcely be said that any infelicities of expression or outright errors that remain are wholly the products of my own ignorance, carelessness, or obstinacy.

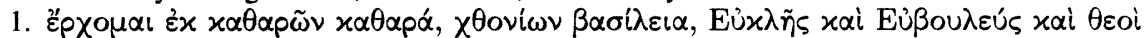

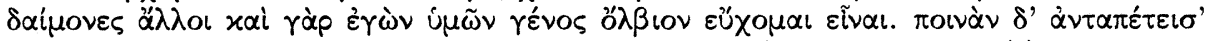

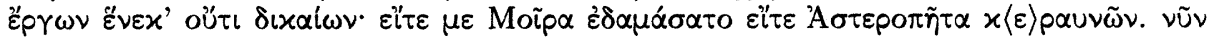

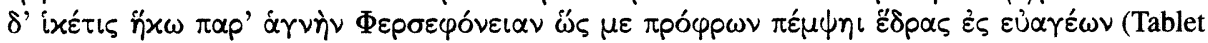
A2, Zuntz 1971:303). The tablet is listed in Kern 1922 as OF 32d. All references to fragments in Kern will be labeled as OF, the testimonies as OT.

2. Nilsson 1935:202. 
Zeus mated with his daughter Persephone, who bore a son, Zagreus, which is another name for Dionysus. Hera in her jealousy aroused the Titans to attack the child. These monstrous beings, their faces whitened with chalk, attacked the infant as he was looking in a mirror (in another version they beguiled him with toys and cut him to pieces with knives). After the murder, the Titans devoured the dismembered corpse. But the heart of the infant god was saved and brought to Zeus by Athena, and Dionysus was born again - swallowed by Zeus and begotten on Semele. Zeus was angry with the Titans and destroyed them with his thunder and lightning. But from their ashes mankind was born.

Surely this is one of the most significant myths in terms of the philosophy and religious dogma that it provides. By it man is endowed with a dual nature-a body, gross and evil (since he is sprung from the Titans), and a soul that is pure and divine (for after all the Titans had devoured the god). Thus basic religious concepts (which lie at the root of all mystery religions) are accounted for: sin, immortality, resurrection, life after death, reward, and punishment. ${ }^{3}$

Read in the light of this Zagreus myth, the tablets' message seems clear. The deceased claims kinship with the gods by virtue of her descent from the Titans. Like the Titans, she claims to have perished by the lightning bolt of Zeus. In her life as an Orphic, she has paid the penalty for the ancestral crime of the Titans through purificatory rituals. Now, purified of the taint of this original sin, she asks Persephone for favorable treatment in the afterlife by virtue of her divine descent from the flesh of Dionysos eaten by the Titans.

Although this myth of Zagreus provides a seductively simple and neat explanation of the cryptic gold tablet, it is unfortunately a modern creation that could not have been known to the "Orphics" of Timpone Piccolo. Indeed, I shall demonstrate that this Zagreus myth is, in fact, a modern fabrication dependent upon Christian models that reconstruct the fragmentary evidence in terms of a unified "Orphic" church, an almost Christian religion with dogma based on a central myth-specifically, salvation from original sin through the death and resurrection of the suffering god. If the evidence is viewed without these assumptions, it can be put back together quite differently.

Ivan Linforth critically reviewed most of this evidence in his 1941 work, The Arts of Orpheus, but the consequences of his analysis have been neglected, in part because of the extreme minimalist stance he took in his definition of Orphism. ${ }^{4}$

3. Morford and Lenardon 1999:223-24.

4. Linforth 1941. Despite his overly narrow restriction of the evidence for Orphism to things bearing the name of Orpheus (thus omitting all of the gold tablets), much of Linforth's critique of the modern construction of Orphism remains valid, even with the discovery of new evidence such as the Derveni papyrus, the Olbia bone tablets, and several new gold tablets with different texts. These discoveries indeed throw new light on the religious phenomena termed "Orphic," but this makes the revival of Linforth's critiques of the monolithic construction of Orphism even more crucial. The Derveni papyrus shows that theogonies ascribed to Orpheus in the fourth century BCE contained 
Recently, Burkert and others have shown that Orphism was not a single unified Church, but is best understood as a collection of diverse counter-cultural religious movements whose major proponents were itinerant "craftsmen" of purification who provided services for a wide variety of customers. ${ }^{5}$ Viewed in this light, the pieces of the Zagreus myth reveal not a single canonical story providing crucial dogma for the "Orphic Church," but rather a multitude of tales told about the death of Dionysos and the punishment of the Titans, each with its own meaning woven out of the differing combinations of the traditional motifs.

In this paper, I distinguish between the ancient tales relating to the dismemberment or sparagmos of Dionysos and the modern fabrication which I call the "Zagreus myth." This myth is put together from a number of elements: (1) the dismemberment of Dionysos; (2) the punishment of the Titans; (3) the creation of mankind from the Titans; and (4) the inheritance humans receive from the first three elements-the burden of guilt from the Titans' crime and the divine spark from the remains of Dionysos. I refer to the entire story as the "Zagreus myth" to reflect the use of the name Zagreus for the Orphic Dionysos by the scholars who fabricated this myth. ${ }^{6}$

Building upon Linforth's critical review, I first examine the pieces of evidence out of which the Zagreus myth has been assembled, demonstrating that the few pieces of evidence used to construct the myth fail to support not only the centrality and early date of the myth (as Linforth has argued), but even the existence of such a story before the modern era. While ancient sources provide testimony for the first three components of the myth, the final component-

some of the elements found in later Orphic material, but the contrast between the Derveni fourgeneration theogony (which reappears in Neoplatonic testimonia) and the six-generation theogony to which Plato alludes confirms that a variety of "Orphic" theogonies were circulating at the time. In his recent work, West 1983 has reduced all of the testimonies to Orphic theogonies to a stemma with two main branches, on the assumption that the variations in the mythic tellings can be charted as neatly as the errors in manuscripts. Even West, however, does not suggest that the Derveni theogony contained the Zagreus myth. If West's reconstruction of OP $\Phi I K$ [ on the Olbia bone tablets as "Orphikoi" is correct, it would provide the first clear reference to people calling themselves Orphics (rather than to rituals and texts called Orphica) before the second century CE. Although the new gold tablets from Hipponion and Pelinna finally provide evidence of a link between the gold tablets and Dionysos, an idea vehemently denied by scholars such as Zuntz, the presence of Dionysos does not imply the myth of Dionysos Zagreus.

5. Burkert 1982. Detienne 1975 refers to Orphism and Pythagoreanism as different chemins de déviance from mainstream Greek religion, a useful term I would apply to the various modes of Orphism itself.

6. Lobeck 1829 seems to be responsible for the use of the name Zagreus for the Orphic Dionysos. As Linforth noticed, "It is a curious thing that the name Zagreus does not appear in any Orphic poem or fragment, nor is it used by any author who refers to Orpheus" (Linforth 1941:311). In his reconstruction of the story, however, Lobeck made extensive use of the fifthcentury CE epic of Nonnos, who does use the name Zagreus, and later scholars followed his cue. The association of Dionysos with Zagreus appears first explicitly in a fragment of Callimachus preserved in the Etymologicum Magnum (fr. $43.117 \mathrm{P}$ ), with a possible earlier precedent in the fragment from Euripides Cretans (fr. 472 Nauck). Earlier evidence, however, (e.g., Alkmaionis fr. 3 PEG; Aeschylus frr. 5, 228) suggests that Zagreus was often identified with other deities. 
the resulting original sin-is an addition of modern scholars. I next show that, viewed without the framework of the Zagreus myth, the pieces of evidence provide testimony for a variety of tellings of the dismemberment myth, which was not the exclusive property of the "Orphics" but rather a well-known element in the Greek mythic tradition. I then explore the Christian models of religion within which the myth was mistakenly reconstructed, noting the role this reconstruction of Orphism played in the turn-of-the-century debates surrounding the nature of the early Church. Finally, I conclude that the gold tablets and their religious contexts have been misunderstood because these texts have been interpreted in terms of a modern fabrication dependent on Christian models, the Zagreus myth. The "Orphic" gold tablets themselves have nothing to do with the stories of sparagmos and anthropogony, but instead supply important evidence for the study of Greek eschatological beliefs.

\section{THE PIECES OF THE ZAGREUS MYTH}

"All of the reconstructions of Orphism have as their base a very small number of secure pieces of evidence and a much greater number of texts whose interpretation seems to me to be quite arbitrary." " Of no part of Orphism is Festugière's comment more true than of the supposed heart of the religion, the myth of the creation of mankind from the dismembered Zagreus. All of the reconstructions of this myth depend upon only six pieces of evidence, fragments whose interpretation is indeed disputable. A number of sources mention the sparagmos of Dionysos and the chastisement of the Titans, ranging from mere allusions as early as the third century BCE to fairly detailed narratives in the first several centuries of the Christian era. These stories, often attributed to Orpheus, include various details, with some versions focusing on the death or rebirth of Dionysos and others on the punishment of the Titans. The most detailed version (and one of the few sources that actually refers to Dionysos as Zagreus) appears in the fifth-century CE Dionysiaca of Nonnos, an antiquarian work that combines as many stories as possible about Dionysos into a lengthy epic. Even this source, however, does not add the creation of mankind to the tale of the dismemberment. The anthropogony, the supposedly crucial element in the myth of Zagreus, is, in fact, only found combined with the tales of the sparagmos and the punishment of the Titans in a single Neoplatonic commentary that dates to the sixth century of the Christian era.

The interpretation of all these tales about Dionysos and the Titans in terms of original sin passed from the Titans to the human race by this anthropogony first appears in 1879, in Comparetti's analysis of the Thurii gold tablets in the

7. "Toutes les reconstructions de l'orphisme ont pour fondement un très petit nombre de témoignages sûrs et un plus grand nombre de textes dont l'exégese me paraît arbitraire" (Festugière 1936:310). 
excavation report. ${ }^{8}$ The gold tablets, with their cryptic references to lightning and unjust deeds, open the flood gates for the new wave of interpretation of the old evidence. Although half a century earlier Lobeck collected the evidence for the stories of the dismemberment of Dionysos by the Titans, their punishment, and even the subsequent anthropogony, he did not refer to a doctrine of original sin, nor is it mentioned in scholarly treatments between Lobeck and Comparetti, such as Zeller's History of Greek Philosophy or the mythological handbooks of Creuzer, Maury, and Welcker. ${ }^{9}$ The scholarship on the first gold tablet from Petelia, published in 1836, contains no reference to the Titanic heritage and the Zagreus myth, or even to Orphism, until Comparetti associated it with the Thurii tablets. ${ }^{10}$ After Comparetti, however, the myth of Zagreus (the dismemberment and punishment plus the anthropogony and original sin) quickly becomes, through the influence of scholars such as Rohde and Harrison, the accepted central dogma of Orphism. ${ }^{11}$

Although Linforth, after his critical examination of the evidence for the reconstruction, concludes that the Zagreus myth should not be considered the central doctrine of Orphism, he does think that the myth existed in some form as early as Pindar. I would take Linforth's critique of the previous scholarship even further. Building upon his examination of the evidence for the various elements of the Zagreus myth, I argue that the Zagreus myth is, in fact, not even a peripheral story for the ancient Orphics, but rather a modern fabrication from a variety of tales in the Greek mythological tradition. In this section, I examine the select few passages on which the reconstruction of the Zagreus myth is based, the same six passages cited by scholars from Comparetti to the present day to support their addition of the anthropogony and the doctrine of original sin to the tales of the dismemberment of Dionysos and the punishment of the Titans. While those engaged in the reconstruction of the Zagreus myth have construed these passages in accordance with the idea of a central but secret myth of the creation of mankind stained with original sin, only one of the passages even mentions the anthropogony, and none supports a doctrine of original sin.

8. Comparetti 1879. Comparetti cites no sources for his interpretation of the gold tablet in terms of Orphic original sin, but scholars have noted Comparetti's part in the anticlerical polemic in the debates regarding the early Church, which I will discuss below (cf. Ziolkowski 1997, esp. p. xxvii).

9. Zeller 1881; Creuzer 1822; Maury 1857; Welcker 1860. Comparetti's interpretation has not yet penetrated into the scholarship of Dieterich 1891, 1893 or even Frazer's discussion of Dionysos Zagreus in the Golden Bough (Frazer 1912).

10. Comparetti 1882:111-18; cf. Comparetti 1910. The earlier publications of the Petelia tablet debated whether the tablet pertained to the Trophonios oracle at Lebedeia or was a Pythian oracle regarding the Trophonios oracle. Cf. Franz 1836:149-50; Goettling 1843.

11. The influential first appearances of this interpretation are in Rohde 1925 (German 1st ed. vol. 2 in 1894) and in Harrison 1922 (1st ed. 1903). The interpretation was then built into the scholarship on Orphism by Kern's arrangement of the fragments in his 1922 Orphicorum Fragmenta, which is still the standard reference. 
The central piece of evidence for the reconstruction of the Zagreus myth comes from the late sixth-century CE Neoplatonist Olympiodorus in his commentary on Plato's Phaedo. Commenting on the prohibition of suicide that Socrates attributes vaguely to the mystery doctrine that our souls are imprisoned in our bodies, Olympiodorus claims that the mythical explanation of the prohibition may be found in a tale told by Orpheus:

Then Dionysus succeeds Zeus. Through the scheme of Hera, they say, his retainers, the Titans, tear him to pieces and eat his flesh. Zeus, angered by the deed, blasts them with his thunderbolts, and from the sublimate of the vapors that rise from them comes the matter from which men are created. Therefore we must not kill ourselves, not because, as the text appears to say, we are in the body as a kind of shackle, for that is obvious, and Socrates would not call this a mystery; but we must not kill ourselves because our bodies are Dionysiac; we are, in fact, a part of him, if indeed we come about from the sublimate of the Titans who ate his flesh. ${ }^{12}$

Olympiodorus claims that the real reason for the prohibition against suicide comes not from the fact that the soul is imprisoned in the body, since that is obvious (at least to a good sixth-century Neoplatonist), but rather comes from the fact that our bodies contain the fragments of Dionysos eaten by the Titans. Guthrie, in his Orpheus and Greek Religion, sums up the predominant interpretation:

From the smoking remnants of the Titans there arose a race which this age had not yet known, the race of mortal men. Our nature therefore is twofold. We are born from the Titans, the wicked sons of Earth, but there is in us something of a heavenly nature too, since there went into our making fragments of the body of Dionysos, son of Olympian Zeus, on whom the Titans had made their impious feast.... Knowing all this, what other aim can we have in life but to purge away as far as possible the Titanic element in us and exalt and cherish the Dionysiac. ${ }^{13}$

Although no other ancient author connects the murder of Dionysos and the creation of mankind, many scholars have assumed that this story was the central, secret dogma of Orphism from earliest times. ${ }^{14}$ Guthrie interprets this passage of

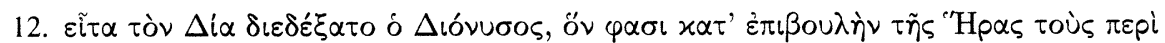

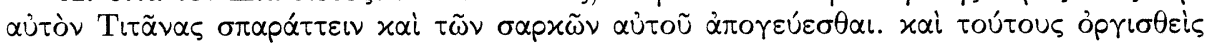

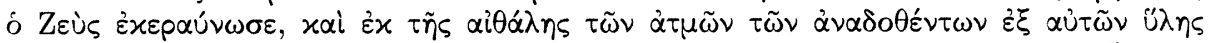

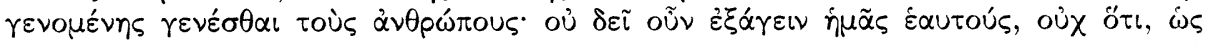

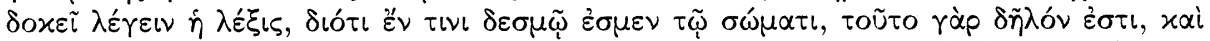

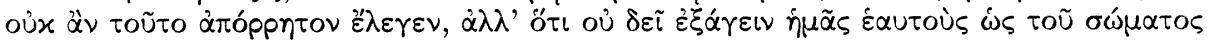

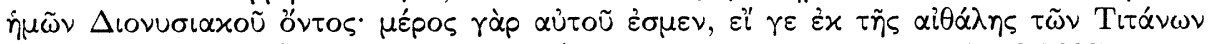

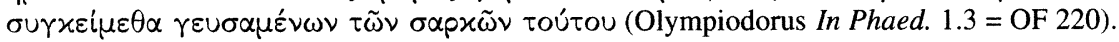

13. Guthrie 1952:83.

14. Proclus does link two of the elements, the punishment of the Titans and the creation of mankind. In his commentary on the Republic, Proclus cites some Orphic poems to support the idea

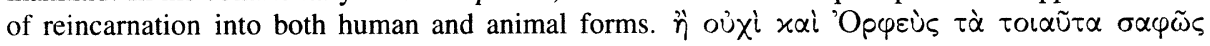


Olympiodorus as evidence that the Orphics had a central dogma of the duality of man's nature, a belief they based on the anthropogonic myth of the creation of man from the ashes of the Titans filled with the fragments of Dionysos.

Linforth, however, has pointed out that Olympiodorus' interpretation, far from representing canonical Orphic doctrine, is rather an idiosyncratic version of the story, created by Olympiodorus in the service of his argument against suicide. Linforth argues, "There can be little doubt that Olympiodorus drew this inference himself in order to contrive an argument against suicide on the basis of the myth.... He does not say that he found the idea that the body of man is Dionysiac in an Orphic poem, nor does he present it as if he had." ${ }^{15}$ Olympiodorus is clearly and consciously innovating, bringing out the previously unnoticed consequences of a detail of the story - the fact that the Titans consumed Dionysos means that they absorbed some of his being.

Brisson, moreover, suggests a particular reason for Olympiodorus' peculiar version of the story. He notes that Olympiodorus uses contemporary alchemical terms to describe the creation of man from the sublimate ( $\alpha i \theta \dot{\alpha} \lambda \eta)$ produced

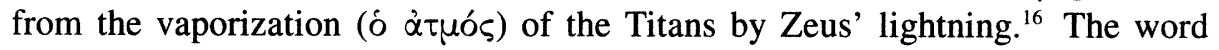

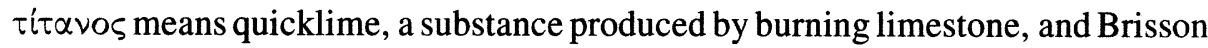
cites two definitions from an alchemical lexicon: titanos is the lime of the

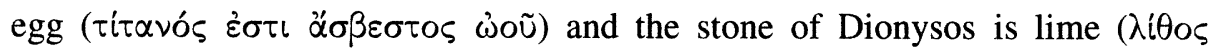

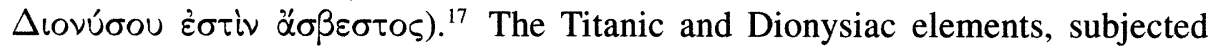
to the fire of Zeus, produce a sublimate, $\alpha i \theta \alpha \dot{\alpha} \lambda$, which the third-century CE alchemist Zosimus equates with the $\pi \nu \varepsilon \tilde{u} \mu \alpha$ that animates the human body. ${ }^{18}$ Thus, Olympiodorus' way of telling the myth makes it a perfect alchemical allegory for the formation of the human $\pi \nu \varepsilon \tilde{u} \mu \alpha$. Olympiodorus refers to both the Titanic and Dionysiac elements that went into the creation of mankind because both have an alchemical significance. He stresses the importance of the Dionysiac element in the formula because of his argument against suicide. While Olympiodorus provides an excellent sample of late antique alchemical speculation, nothing in his telling of the myth provides any evidence for an early Orphic doctrine of the divinity or salvation of mankind from the Dionysiac bits absorbed by the Titans. ${ }^{19}$

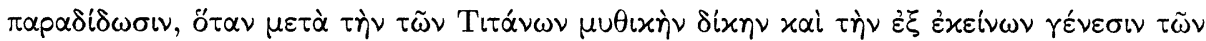

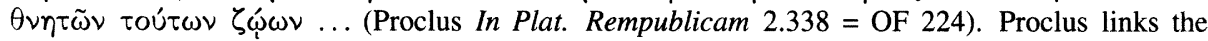
creation of all living beings with the mythic punishment of the Titans, but this tale of punishment is more likely to be the result of the Titanomachy rather than the murder of Dionysos. Moreover, since all living creatures, not simply humans, are created from the Titans in this telling, the story cannot have included an element of an original sin that burdens the human race.

15. Linforth 1941:330.

16. "En définitive, en foudroyant les Titans, Zeus aurait procédé à une opération alchimique, dont aurait résulté l'être humain" (Brisson 1992:493-94, reprinted in Brisson 1995).

17. Berthelot 1888 II: $14.2,10.2$.

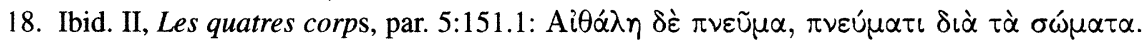

19. Cf. Linforth's assessment, "The belief that this myth transcends in importance all the other things that were contained in the poetry of Orpheus or were otherwise associated with his name 
West, whose Orphic Poems is the most recent comprehensive treatment of the subject, agrees with Linforth that the Dionysiac element in mankind is an invention of Olympiodorus, but he persists in the idea that the anthropogony from the blasted Titans is an early element in the myth:

Although Olympiodorus' interpretation of the Orphic myth is to be rejected, there is no denying that the poet may have drawn some conclusion from it about man's nature; ... any such conclusion is likely to have concerned the burdens of our inheritance. The fact that the Titans had eaten Dionysus was merely evidence of their wickedness, it did not introduce a saving element into our constitution. It is to the living Dionysus that we must turn for salvation. ${ }^{20}$

West still sees original sin and salvation through the resurrected Dionysos as Orphic doctrines for which Olympiodorus' commentary provides firm evidence. Even if there is no Dionysiac nature in mankind, the Titanic nature still lingers in humanity, creating the need to pay reparation for the ancestral crime.

Despite the fact that nothing in Olympiodorus implies the idea of guilt inherited from the Titans, scholars from Comparetti to West have cited several specific fragments of evidence to support the idea that the Orphics believed, from a very early date, in a Titanic nature of man that is a consequence of the anthropogony from the ashes of the Titans. As I examine the next few pieces of evidence, I shall argue, to the contrary, that the anthropogonic part of the myth of Zagreus does not appear to be linked with the murder of Dionysos and the punishment of the Titans in any evidence before the Neoplatonists, and that the doctrine of original sin derived from it is, in fact, an invention of modern scholars.

Those who wish to date the Zagreus myth derived from Olympiodorus to the sixth century BCE instead of CE adduce as evidence the statement of Pausanias that Onomakritos was the first to put the Titans in the myth of Dionysos. "Homer first introduced the Titans into poetry, making them gods down in Tartaros, as it is called; the lines are in the oath of Hera. Onomakritos, borrowing the name from Homer, composed the rites of Dionysos and made the Titans the authors of the sufferings of Dionysos." ${ }^{21}$ Onomakritos, according to Herodotus (6.7.3), kept the oracle collection of the Pisistratids in Athens until he was exiled for forging some oracles of Musaeus, son of Orpheus. As a result, Onomakritos has been described

probably rests in large part on the assumption that it formed the basis for an Orphic doctrine of the divinity of man. The profound significance of such a doctrine, however, is so dazzling and impressive that scholars have been somewhat uncritical in their use of the testimony which is supposed to supply a warrant for it in Orphic religion" (Linforth 1941:308).

20. West 1983:166.

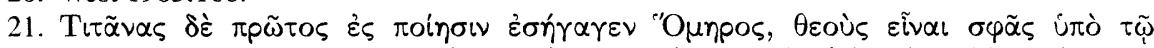

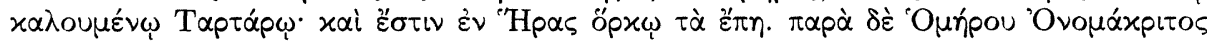

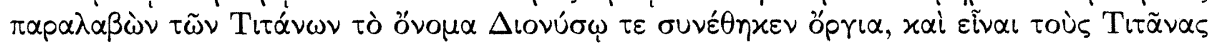

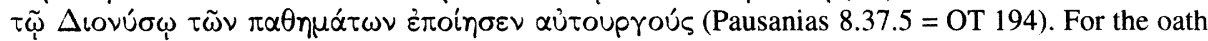
of Hera passage, see Iliad 14.279 and Hom. Hymn to Apollo 334-36. 
according to this argument as an Orphic priest, one of the chief formulators of Orphic dogma and even the one responsible for the so-called Orphic interpolations in the Odyssey of Homer during the Pisistratid recension. ${ }^{22}$ If Pausanias is to be trusted, the date of some tale of the Titans murdering Dionysos could be fixed to the sixth century BCE. However, as Linforth argues, scholars in the Hellenistic era and later, who were trying to determine the real authorship of various poems attributed to Orpheus, often attributed them to Onomakritos, who was already famous as a forger:

No one else throughout antiquity quotes from works of Onomacritus or makes any allusion to them. It is an extremely probable inference from these considerations that when Pausanias says Onomacritus he means Ps.-Orpheus, that all his quotations from Onomacritus are really quotations from Orphic poems, and that there were actually no poems by Onomacritus and never had been. His words cannot be taken as a statement of fact, but only as an echo of speculations concerning the authorship of Orphic poetry. ${ }^{23}$

Pausanias therefore only attributes the introduction of the Titans into the story of the murder of Dionysos to some poem claiming to be by Orpheus and gives the name of the famous forger Onomakritos as the author of the forgery. His testimony can hardly be used to set the date much earlier than his own time, in the second century CE. Moreover, while it does establish the presence of the Titans in the story of the murder before the sixth century $\mathrm{CE}$, i.e., a link between the first two elements of the Zagreus myth, it still furnishes no evidence that the third element, the creation of mankind from the Titans' remains, was related before the Neoplatonists.

Many scholars argue that the evidence of a reference in Plato's Laws to a

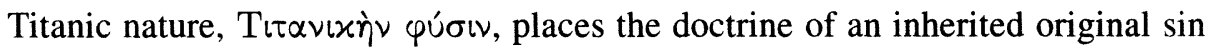
(and thus, necessarily, an anthropogony) back into the Classical era:

Next on this path to liberty would be the wish not to submit to the rulers; and, following this, to flee the service and authority of father and mother and the elders; and, near the end, to seek not to obey the laws, and, at the end itself, to pay no mind to oaths and promises and the entirety of the gods, displaying and imitating the fabled ancient Titanic nature, wherein they return to the same things, experiencing a savage time, never to cease from evils. ${ }^{24}$

22. Guthrie emphasizes the role of Onomakritos, e.g., Guthrie 1952:13-14. Macchioro holds that the Orphics of Pisistratean Athens were responsible for interpolations in Homer as part of their "conquest of Greece" (Macchioro 1930:151-56).

23. Linforth 1941:353. Cf. Pausanias' attribution of poems to Onomakritos: 1.22.7; 8.31.3; 9.35.5. In each case, it seems likely that he is referring to a poem attributed to Orpheus that he believes is not actually by Orpheus.

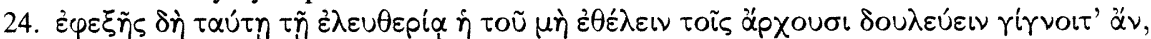

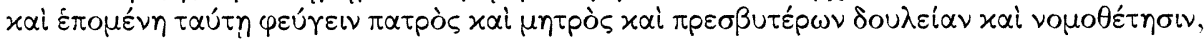


Even if the Dionysiac nature in mankind is a modern misunderstanding of an Olympiodoran innovation, this Titanic nature, it is claimed, can only refer to the myth of Zagreus and the creation of man from the ashes of the Titans. Nilsson claims that this passage is "fully understandable only in the light of their role in Orphism, their dismembering of the Divine Child, and of the Orphic doctrine that human nature had incorporated a part of the Titans. Even if it is not mathematically demonstrable, it is practically certain that this expression is due to the Orphic myth referred to." 25 Linforth, however, has demonstrated that this passage does not identify mankind with its Titanic heritage, but rather compares the behavior of certain degenerate people in Plato's hypothetical society in the Laws with the behavior of the Titans. ${ }^{26}$ In this passage, Plato describes a progressive degeneration of society, culminating in the disregard of oaths and lack of respect for the gods-in short, behavior just like that of the Titans, a return to the savage state of those early mythic times. No Orphic tale of the murder of Zagreus need be supposed, since the Titans are depicted as violent and opposed to rightful rule even in Hesiod: this second element of the Zagreus myth, the chastisement of the Titans, is indeed often included in a story as the result of the war of the Titans against Zeus and the other gods, an event completely unconnected with the tale of the murder of Dionysos. The stories of the Titanomachy, moreover, are well enough known to be referred to without further explanation, in contrast to the supposedly secret dogma of the murder of Zagreus. As Linforth has argued, then, Plato is making a comparison between the subversive behavior of certain people in society and the subversive behavior of the Titans in their war against the rightful authority of the gods. He is not attributing this behavior to a Titanic element in the subversives. The Titanic nature mentioned in Plato, therefore, provides no evidence for a secret Orphic doctrine of original sin stemming from the Titans' murder of Dionysos.

By contrast, when Plutarch, some five hundred years later, mentions the irrational, disorderly, and violent nature in humankind, he clearly is referring to a tale of the Titans' murder of Dionysos, although he does not include an anthropogony:

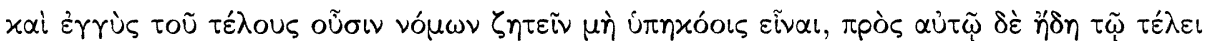

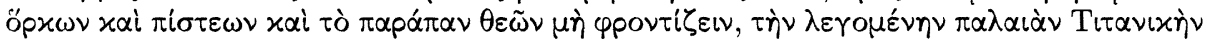

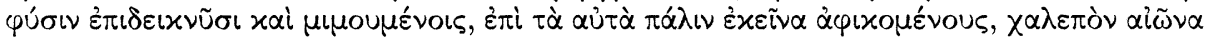

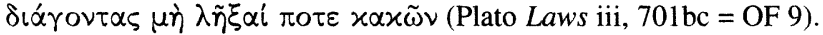

25. Nilsson 1935:203.

26. Linforth 1941:342-44. Alderink agrees that the passage sets out a comparison rather than an identification, but still thinks that the reference to the Titans implies the dismemberment story (Alderink 1981:70-71). Alderink follows Bianchi's distinction between péché antécédent and péché originel in that the crime of the Titans is not a crime by humans for which all mankind bears the guilt, but rather a crime by mythic creatures that serves as a model or pattern for all the crimes of humanity (Bianchi 1966:119-26). Alderink and Bianchi, however, still see the Titans' péché antécédent as the reason for the later crimes of humanity rather than a parallel or analogous case, and they assume too readily that it is the dismemberment and not the Titans' many other crimes that are alluded to in Plato. 
It would perhaps not be wrong to begin and quote lines of Empedokles as a preface.... For here he says allegorically that souls, paying the penalty for murders and the eating of flesh and cannibalism, are imprisoned in mortal bodies. However, it seems that this account is even older, for the legendary suffering of dismemberment told about Dionysos and the outrages of the Titans on him, and their punishment and their being blasted with lightning after having tasted of the blood, this is all a myth, in its hidden inner meaning, about reincarnation. For that in us which is irrational and disorderly and violent and not divine but demonic, the ancients used the name, "Titans," and the myth is about being punished and paying the penalty. ${ }^{27}$

Plutarch knows the story much as it appears in Olympiodorus, with the Titans first tearing Dionysos apart and tasting his flesh, then being blasted by the lightning bolt of Zeus, but one cannot simply presume further that Plutarch's story implies the conclusion of Olympiodorus, the anthropogony from the ashes of the Titans, much less an inherited stain upon mankind. Certainly, he does state that the myth has to

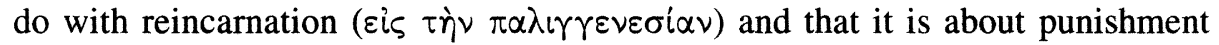

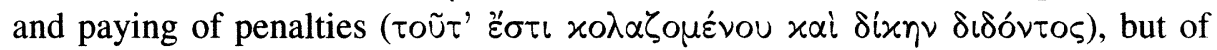
a resulting anthropogony there is no mention.

Plutarch, in fact, avoids making the connection made by modern interpreters, namely, that the Titans were imprisoned in human form as a result of eating the flesh of Dionysos, in the same way that daimons, in Empedokles, take on mortal incarnation as punishment for the crime of murder and cannibalism. ${ }^{28}$ Plutarch instead reads the chastisement of the Titans as a mythic allegory of the punishment of incarnation for the crime of meat-eating, rather than, as modern scholars have assumed, as the outstanding example of how eating flesh was the crime that led to the incarnation of humans in the first place. Plutarch's telling links the murder of Dionysos with the chastisement of the Titans, but it does not include the element of anthropogony which could then be used to create a causal link between the Titans' murder and the punishment of mankind. Such a causal link

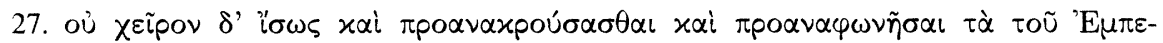

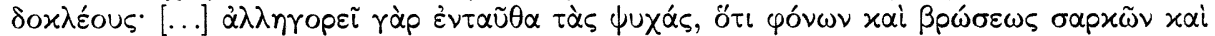

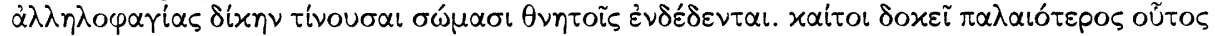

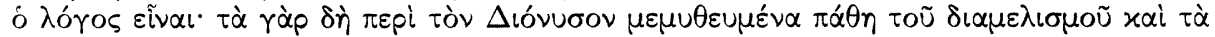

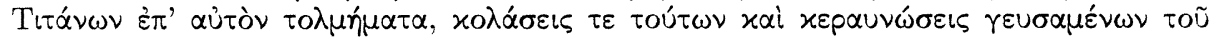

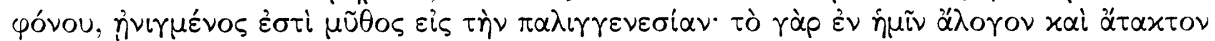

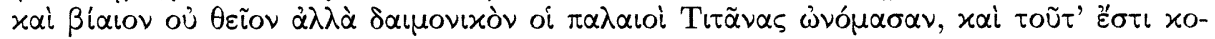

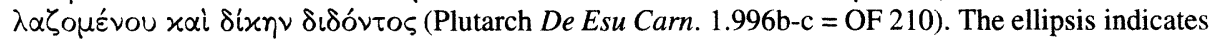
the place where a quote from Empedokles is presumed to have been but is not present in the text.

28. Linforth points out: "Either he was unacquainted with the version of the myth which we first find unmistakably in Olympiodorus, and according to which the birth of men from the Titans was brought into immediate connection with the outrage on Dionysus, or for some cause he suppressed it" (Linforth 1941:337). Linforth, however, fails to separate the idea of the Titans' punishment by lightning and/or imprisonment in Tartaros as an analogy for the punishment of humans from the idea that the Titans' punishment is actually imprisonment in humans who suffer punishment. 
would transform the allegory into an aition, the myth with a hidden enigmatic meaning into a literal tale of cause and effect. The ancients do use the Titans as a symbol of the evil impulses in humans; they do not, however, say that the evil and irrational in man is the Titan in man. Plutarch's phrasing is ambiguous, but he is producing an allegorical interpretation of the ancient myth, explaining the inner, moral meaning (i.e., the Empedoklean doctrine of reincarnation) that the story reveals enigmatically (ñvㄱévos) rather than citing the myth as an aition, the cause of human reincarnation and punishment.

Plutarch's allegorical interpretation of the myth of the Titans' murder of Dionysos may have come from Xenokrates, a pupil of Plato who also wrote a treatise against the eating of flesh. A cryptic reference preserved in Damascius' commentary on the Phaedo, which dates to the beginning of the sixth century CE, provides this fifth piece of evidence for the construction of the Zagreus myth. ${ }^{29}$ "We are in some kind of custody ( $\varphi p o u ́ p \alpha$ ): Using these principles, we shall easily prove that 'the custody' is not the Good, as some say, nor pleasure, as Noumenios would have it, nor the Demiurge, as Paterios says, but rather, as Xenokrates has it, that it is Titanic and culminates in Dionysos." ${ }^{30}$ Xenokrates apparently made some connection between the ypoúpa of Plato and the myth of the Titans and Dionysos. Damascius' summary of Xenokrates' idea gives no clue as to what the connection might have been, but it seems likely that Xenokrates, like Plutarch, was explaining the myth as an allegory of the punishment of a human soul that eats meat. Linforth comments, "In any case, the idea that men were born from Titans is clearly avoided by Plutarch; and that it was also avoided by Xenocrates is made the more likely by the fact that according to his view (fr. 59 Heinze), as we learn from Censorinus, the human race had existed forever." ${ }^{\prime 11}$ Not only Plutarch, then, but also Xenokrates knew a myth of the Titans' dismembering and eating of Dionysos. Since they do not connect the anthropogony story, such as it is found in Olympiodorus, with the myth they know of the murder of Dionysos and the punishment of the Titans, it seems most probable that they used the Titans as a mythic analogy for the fate of the human soul that consumed meat, rather than identifying the Titans' consumption of Dionysos as the cause of all human incarnation. Plutarch and Xenokrates do not include the anthropogony story because that mythic element does not fit with the points they are making in their telling of the murder of Dionysos.

29. This commentary has also been attributed to Olympiodorus, e.g. by Norvin, but Westerink argues for the attribution to Damascius (Westerink 1977, vol. 2:15-17).

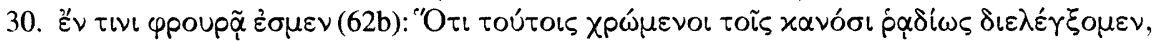

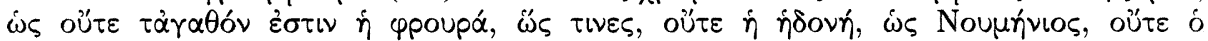

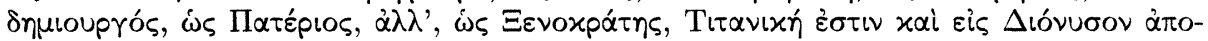
xоричоũtal (Xenokrates fr. 20 = Damascius In Phaed. 1.2).

31. Linforth 1941:339. Brisson 1992:497 concurs: “Or, la version de la théogonie orphique, connue par Xénocrate et par Platon, ne se terminait pas sur une anthropogonie, comme semble le laisser supposer l'analyse du passage de Plutarque qui y fait allusion." 
Of the fragments that are cited as evidence, then, for the existence before Olympiodorus of a tale with all the elements of the Zagreus myth-the anthropogony from the ashes of the Titans punished for the dismemberment of Dionysos and the subsequent Titanic nature in man stained with original sin-not one indicates that the anthropogony was known or that the crime of the Titans was regarded as more than an allegory for the crimes of mankind, a symbol used by the ancients to convey wise prohibitions and warnings. On the contrary, Xenokrates would have rejected such an anthropogony, while Plutarch, if he had even known of it, would surely have cited it in his argument. Plutarch knows the story of the Titans' murder of Dionysos and, most likely, Xenokrates does too, but the passage from Plato may not even refer to it. The passage from Pausanias tells us that someone made the Titans the murderers in the story of the death of Dionysos, linking the elements of the sparagmos of Dionysos with the punishment of the Titans, but even if this innovation occurred before Xenokrates, there is nothing to indicate that the anthropogony was added at the same time, much less that the whole tale was the crucial story for the Orphics.

\begin{tabular}{|c|c|c|c|c|}
\hline & $\begin{array}{l}\text { ismemberment } \\
\text { of Dionysos }\end{array}$ & $\begin{array}{l}\text { Punishment } \\
\text { of the Titans }\end{array}$ & Anthropogony & $\begin{array}{l}\text { Original Sin } \\
\text { for Humans }\end{array}$ \\
\hline $\begin{array}{l}\text { Olympiodorus } \\
\text { - sixth CE } \\
=\text { OF } 220\end{array}$ & yes & yes & yes & no \\
\hline $\begin{array}{l}\text { Pausanias } 8.37 .5 \\
\quad \text { - 2nd CE } \\
\quad \text { = OT } 194\end{array}$ & probably & probably & no & no \\
\hline $\begin{array}{l}\text { Plato Laws 701c } \\
\quad \text { - 4th BCE } \\
=\text { OF } 9\end{array}$ & no & yes & no & no \\
\hline $\begin{array}{l}\text { Plutarch } \\
\quad \text { - 2nd CE } \\
\quad=\text { OF } 210\end{array}$ & yes & yes & no & no \\
\hline $\begin{array}{r}\text { Xenokrates fr. } 20 \\
\text { - 4th/3rd BCE }\end{array}$ & $\begin{array}{l}0 \\
0\end{array}$ & probably & no & no \\
\hline
\end{tabular}

These five pieces of evidence form the basis, in the scholarship from Comparetti to West, for the assumption that the Zagreus myth, with its doctrine of original sin, stands at the center of Orphism from the sixth century BCE. One other important piece of evidence was added to Comparetti's original argument: a fragment, presumably from Pindar, quoted in Plato's Meno. H. J. Rose introduced this fragment into the debate to prove the existence of an Orphic doctrine of original sin from the late Archaic age. ${ }^{32}$ 
"Those from whom Persephone receives the penalty of ancient grief, in the ninth year she sends back their souls to the sun above, and from them grow glorious kings and men swift with strength and great in wisdom; at the last they are called sacred heroes among men." ${ }^{33}$ Despite all of his doubts about the Zagreus myth, even the skeptical Linforth accepts (wrongly, as I shall show) the explanation of Rose that this line can only refer to Persephone accepting a recompense from humans for the murder of her son Dionysos by the Titans, ancestors of mankind. He does note, however, "It is a curious thing that nowhere else, early or late, is it said or even expressly implied that guilt descended to men in consequence of the outrage committed upon Dionysos. Even Olympiodorus does not say so." ${ }^{\prime 34}$

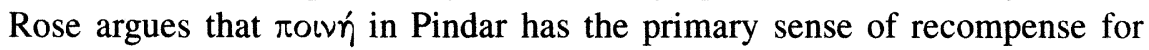

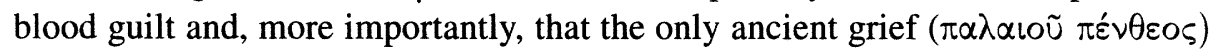
for which Persephone could accept recompense is the murder of her son. ${ }^{35}$ Indeed, if the grief must be Persephone's, it might be hard to find an alternate explanation, but, as Linforth himself suggests, the grief may not be Persephone's at all, but may refer to the souls passing through a series of incarnations. He adds, "Another possibility is that the $\pi \varepsilon \varepsilon^{\prime} \theta 0 \varsigma$ itself is the $\pi$ o $\nu$ ' (the genitive being appositional), so that Persephone is said to accept as atonement the misery of previous existences." ${ }^{36}$ The syntax may be awkward, but not much more so than in Rose's reading, and the idea of an individual paying a penalty for the various crimes committed by the self or an ancestor in a previous existence has parallels throughout Greek literature from Homer on. ${ }^{37}$

More importantly, Rose's whole argument, as he himself admits, depends upon the idea that mankind has inherited a dual nature from the crime of the Titans, an idea that stems from the sixth-century $\mathrm{CE}$ alchemical allegory of Olympiodorus:

For if men are not the descendants of the Titans (again it is of little moment whether they were actually called by this name so early), what share have they in the guilt which grieves Persephone and causes her to accept an atonement at their hands? Again, if their ancestors did not devour the divine infant, what claim have they, their satisfaction once made, to such

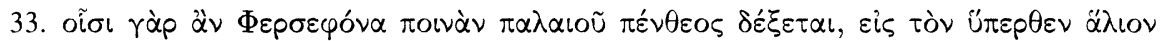

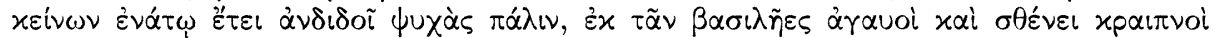

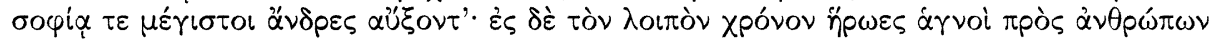

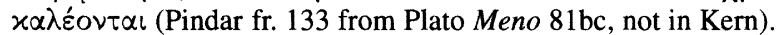

34. Linforth 1941:350. West, on the other hand, sees other possible explanations of the fragment (West 1983:110n. 82). However, despite his acceptance of Linforth's arguments against all the other evidence used to support an early date for the Zagreus story, he nevertheless includes the story, on the basis of its similarity to the tale of the infancy of Zeus in Crete, in the Eudemian theogony, which he dates to fourth-century Athens.

35. "The one thing which I personally find puzzling about the whole phrase is that any one acquainted with Greek mythology should ever have interpreted it in any other way" (Rose 1936:86).

36. Linforth 1941:347. Seaford 1986 concurs with this reading and also suggests that the Titanomachy is a more likely crime if the Titans are considered the forebears in question.

37. This element of humans paying the penalty for the crimes of their ancestors is discussed below in the next section. 
especial grace as she shows them? Mere Titan-men might well be content if they escape Tartaros, with such an inheritance of guilt; these pardoned sinners are raised to the highest rank on earth and afterwards heroized. ${ }^{38}$

But even if the Titans were thought to be the ancestors of mankind, no ancient author ever suggests that mankind does have a share in the guilt for their murder of Dionysos, and not even Olympiodorus suggests that the Dionysiac pieces absorbed into the sublimate out of which mankind was formed somehow make Persephone benevolently disposed to mankind. Rose's argument, plausible if the dual nature of mankind is assumed to be a well-known central doctrine of Orphism, collapses when the evidence is examined carefully. By Rose's own argument, the penalty of ancient grief makes no sense as the recompense paid to Persephone for the Titanic murder of her son Dionysos.

None of the evidence, then, that is cited in support of the central presence from earliest times in Orphism of a myth, linking the dismemberment of Dionysos Zagreus and the chastisement of the Titans with the anthropogony and the burden of Titanic guilt, can withstand serious scrutiny. In the next section, I argue that this evidence points instead to a number of stories about the dismemberment, the punishment of the Titans, and the creation of humans, woven together in a variety of ways that reveal the concerns of the tellers at different times.

\section{GATHERING THE PIECES OF THE ZAGREUS MYTH}

This modern myth of Zagreus, then, has been dismembered, and its pieces lie strewn about, apparently unconnected with one another. The task that now remains is to gather anew the scattered fragments of the myth of Zagreus, to find places for the disparate pieces of evidence for the story. The myth of the sparagmos of Dionysos, I would argue, was not a single tale containing a timeless doctrine, but grew and changed over time, being told and retold in different ways according to the interests of the teller, who combined this motif with others to suit the occasion. ${ }^{39}$ This story will naturally remain for us a collection of fragments, rather than a neatly unified whole, because of the enormous gaps in our evidence and the nature of the evidence that does remain, mostly in the form of references and citations by the Neoplatonists. ${ }^{40}$ Nevertheless, this collection of fragments

38. Rose 1936:88. In Rose's response to Linforth (Rose 1943), he can do no more than reiterate the fact that he can think of no other way to interpret the passage.

39. As J. Z. Smith puts it: "The work of comparison, within and without the area of Late Antiquity, requires acceptance of the notion that, regardless of whether we are studying myths from literate or non-literate cultures, we are dealing with historical processes of reinterpretation, with tradition. That, for a given group at a given time to choose this or that mode of interpreting their tradition is to opt for a particular way of relating themselves to their historical past and social present" (Smith 1990:106-107, original emphases).

40. The basic problem, as Boyance notes, is that the evidence comes in fragmentary form in Neoplatonic commentators. "Les modernes s'y sont souvent mépris et cru voir dans les mythes eux- 
presents a more accurate picture of the whole than the fabricated Zagreus myth, construed as a tale that always signified the sinful nature of mankind and the hope of redemption.

Each individual retelling, examined in its context, sheds light on the whole tradition. However, three important strands must be distinguished in the various myths that appear in the evidence, for the presence of one strand in a piece of evidence need not imply the others:

(1) The first strand contains the motifs of dismemberment and cannibalism, specifically the sparagmos associated with Dionysos and the eating of an infant.

(2) The second strand is the idea of punishment for past wrongdoings, both for the Titans and for mortals.

(3) The third strand that is woven into these stories is the generation of human beings, the anthropogony.

The final element of the Zagreus myth, the original sin that burdens mankind, is, as we have seen, not actually present in any of the tellings of the tale before 1879 .

Much of this evidence is reviewed by Linforth, but he fails in the final analysis to separate all the elements of the myth, which leads him to take evidence for parts of the Zagreus myth as evidence for the whole. He reluctantly concludes (p. 350) that the weight of the evidence suggests that the Zagreus myth was probably known as early as Pindar, although he does argue that it was no more important than other versions of the sparagmos story. West too fails to separate the elements and assumes that the presence of the Titans in the dismemberment story implies all of the elements of the Zagreus myth. ${ }^{41}$ All these motifs can be found woven into various stories throughout the Greek mythic tradition, but the significance of these elements and of the whole story that contains them is not the same in all the various permutations. ${ }^{42}$

The earliest tellings of the sparagmos of Dionysos are impossible to trace. Dionysos and his maenads are associated with deaths through dismemberment in a number of myths. ${ }^{43}$ Perhaps the motif of dismemberment and subsequent

mêmes des éléments tardifs qui ne sont que les éléments philosophiques introduits arbitrairement par l'exégèse. C'est un peu comme si nous ne connnaissons l'Antre des Nymphes de l'Odyssée que par Porphyre" (Boyancé 1963:11).

41. Accordingly, West locates the Zagreus myth in his Eudemian theogony, which he dates to the fourth century BCE, although not in his earliest Protogonos theogony (of which he sees the Derveni theogony as a truncated variant). For serious critiques of West's reconstruction, see the reviews by Casadio 1986 (esp. p. 311), Brisson 1985, and Finamore 1987. The failure to separate the different elements of the myth also troubles the otherwise fascinating treatment by Scalera McClintock 1995.

42. Only in Olympiodorus are all three strands combined-the rending of the infant Dionysos, the punishment of the Titans for cannibalism, and the birth of humans. Even in Olympiodorus, however, the motifs of punishment and anthropogony do not imply any idea of original sin that burdens all of mankind.

43. The tale of Pentheus is the most famous, but the stories of Orpheus, Lycurgus, and perhaps Actaeon, also fall into this type. 
rebirth were borrowed from the Egyptian story of Osiris; ${ }^{44}$ perhaps this element came from ancient shamanic ritual practices. West, following the shamanic model proposed by Jeanmaire and Dodds, argues that the motif of sparagmos and rebirth is a feature of shamanic initiation in cultures throughout the world and that its presence, both in the Zagreus myth and in other Greek myths (e.g., the cauldron of Medea or the experience of Pelops), indicates a survival of shamanic initiation ritual in Greek culture. ${ }^{45}$ The notion of survivals is, in itself, not unproblematic, nor does the origin of a myth explain its function, but the shamanic model does give an account for the presence of this kind of motif and suggest a scenario for its function. As West demonstrates, various references in Plato and other authors of the Classical period to Korybantic initiation rituals, as well as the descriptions from the Hellenistic era and even later, all seem to indicate that this kind of initiation, with its ritual experience of being torn apart and reborn, did not belong solely to the depths of the primitive past but had meaning for people living in the historical periods from which the evidence comes.

This initiatory scenario, however, is not the only (or even the most frequent) context in which the myth appears. In the first fully extant telling of the myth of the sparagmos and rebirth of Dionysos, Diodorus in fact explains it as an allegory of the process of winemaking. Dionysos, who represents the grape and the vine, is torn to pieces by the workers of the earth ( $\gamma \varepsilon \omega p \gamma o i$, who are assimilated to

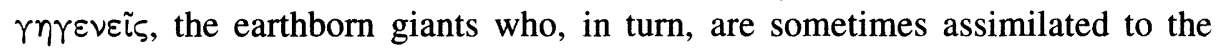
Titans). ${ }^{46}$ However, the story of the dismemberment was retold many times in different ways by ancient sources who saw the myth as something other than an allegory of nature. Later thinkers may have used it as an allegory for diakosmesis, the physical process by which the original unitary substance of the universe was dispersed. Plutarch tells how Dionysos is the name the wise use to describe the transformation of the cosmos from the single fire to the diverse states of being:

The wiser folk, concealing it from the masses, call the transformation into fire by the name of Apollo because of the oneness of that state, or by the name of Phoebus because of its purity and lack of defilement. As to the manner of his birth and diakosmesis into winds, water, earth, stars, plants, and animals, they describe this experience and transforma-

44. Herodotus mentions the identification of Osiris and Dionysos. $(2.42,47,123,144,156)$ The connection with Egypt has been much debated, but, whether the dismemberment myth was the early cause of the identification or the late Hellenistic result, the connection could not have occurred had the myth not found a significance within the Greek religious tradition. Cf. Plutarch De Iside et Osiride 35.364f-365a.

45. West 1983:143-63. Cf. Dodds, "The Greek Shamans and the Origins of Puritanism," in Dodds 1951:135-78; Jeanmaire 1939:147-223.

46. Diodorus Siculus 3.62-65 = OF 301. Cornutus seems also to have explained the dismemberment story as an allegory of the winemaking process (Cornutus fr. 30 ). Cf. the references to Oinos in Proclus In Cratyl. p. $108=$ OF 216. West cannot work this testimony into his reconstruction, so he dismisses it as an innovation of the compiler of the Rhapsodies and then omits it from his summary of the Rhapsodies (West 1983:142, 245-46). 
tion allegorically as "rending" and "dismemberment." They name him Dionysus, Zagreus, Nyctelius, Isodaites, and they construct allegories and myths proper to the stories of death and destruction followed by life and rebirth. ${ }^{47}$

The Neoplatonists, for their part, cite the myth frequently as a tale about the One and the Many, the diffusion of divine power throughout the entire material universe. Linforth summarizes some of the Neoplatonic readings of the story. "Dionysus, who, though he is torn to pieces, is reborn whole and sound, is the Soul of the universe, which is divided and yet retains its indestructible unity. The Titans represent the evil principle of division." ${ }^{48}$ Even though the earliest variants of the tale date centuries earlier, most of the references to the dismemberment of Dionysos in fact come from the Neoplatonists or their contemporaries, indicating perhaps that the myth became particularly meaningful in this period.

Often entwined with the motif of sparagmos is the idea of cannibalism, specifically the eating of children. Not only is this a favorite motif in the tragic retellings of myths, but the threat to the infant god by Titans can be found as early as the story of the infant Zeus and his child-devouring father, Kronos, recounted in Hesiod. ${ }^{49}$

When the eating of the child becomes linked with the dismemberment, the sparagmos is transformed from a dissolution preceding a rebirth to a brutal and savage murder. Detienne's analysis of the story of the dismemberment in Dionysos Slain highlights this important development in the myth. Detienne also points to the language of sacrificial practice in various versions of the myth, in particular the description of the peculiar cooking process mentioned in the pseudo-Aristotelian "Problem." 50 The Titans pervert the normal sacrificial practice by first boiling then roasting their victim, who has been cut up with a sacrificial knife, not torn apart with bare hands. Detienne sees this story as an Orphic protest against the sacrifice and the eating of meat that play an important role of the religion of the polis:

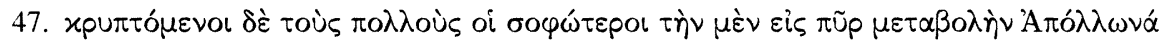

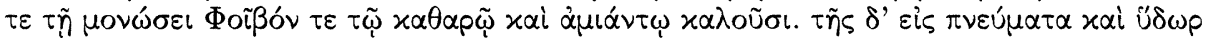

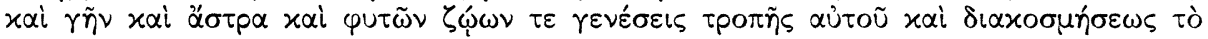

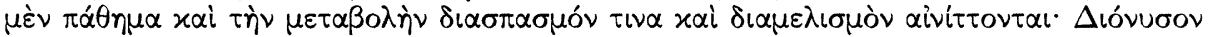

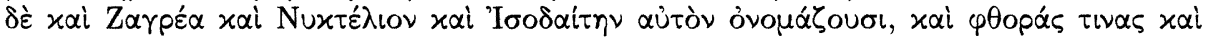

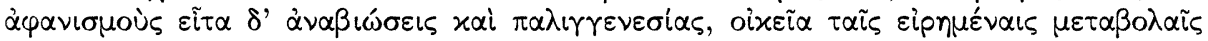

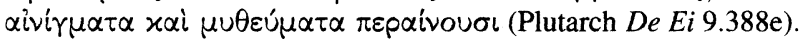

48. Linforth 1941:320. Cf. e.g., OF 210, 211.

49. West 1983 and Guthrie 1952 both provide imaginative reconstructions of the process by which this story became attached to the infant Dionysos and then linked to the dismemberment myth. Guthrie still subscribes to the idea of the Thracian invasion of Dionysos, and West is perhaps a bit uncritical in his attribution of certain elements of the story to Crete or to Delphi, but both reconstructions on the whole remain fairly plausible. West fails to argue, however, how the anthropogony was attached to these stories.

50. Ps.-Aristotle Problemata 3.43 (Bussemaker). Cf. Iamblichus Vita Pythag. 154; Ath. 656b. 
To abstain from eating meat in the Greek city-state is a highly subversive act. Such is the cultural and religious backdrop of the story of the death of Dionysos told by the disciples of Orpheus. This is a myth about the blood sacrifice, and it stands at the center of a system of thought that rejects this kind of sacrifice and establishes itself in open opposition to the official tradition. ${ }^{51}$

By linking the sparagmos and cannibalism, the myth of the dismemberment of Dionysos becomes an expression of a protest against the mainstream religious tradition, wherein the sacrificial ritual which comprises one of the fundamental acts of the mainstream religious tradition is depicted as a brutal act of savage cannibalism. Certainly this reading of the myth fits in with the doctrines of Empedokles, and it seems likely that, when Xenokrates and Plutarch related the myth in their condemnations of meat-eating, they had this meaning in mind. That the story of the dismemberment of Dionysos was interpreted by some as a condemnation of the meat-eating order of the polis religion, however, by no means guarantees that it always had this significance for those relating the myth; this strand was woven into many different kinds of tales. ${ }^{52}$

The second strand in the tradition is the punishment of the Titans, a tale that goes back to Hesiod and reappears in most of the stories about the Titans. Most often the Titans are being punished for their war against Zeus and the other gods, but some stories attribute the punishment to the murder of Dionysos. The chastisement of the Titans may be described as imprisonment in Tartaros, as in Homer and Hesiod, or in terms of the lightning strikes of the angry Zeus, or, in some cases, a combination of the lightning bolts and imprisonment, as in Aeschylus' Prometheus Bound, which ends with Prometheus blasted down into the bowels of the earth by Zeus' bolts. ${ }^{53}$ In Plutarch (and probably in Xenokrates), this chastisement of the Titans serves as an analogy to the punishments that humans receive for the crimes of their previous existences, a mythic description of the familiar Greek idea of the delays of divine vengeance.

51. Detienne 1979:72.

52. Detienne, in his efforts to prove that the myth had this meaning, neglects the possibility that the myth may originally have described the murder of Dionysos as a sparagmos followed by omophagia and later been revised for the purpose of the argument against the eating of meat. He dismisses the versions that seem to indicate a sparagmos as misleadingly vague or simply mistaken in the details, accepting as accurate only those which indicate a sacrificial ritual. Detienne brilliantly teases out the system of oppositions involving raw and cooked, savage and civilized, primitive and advanced, but he fails to allow the possibility that the same tale could have been told with the focus on other oppositions, such as, e.g., the Neoplatonists' Many and One. His insistence that the story must always have been told in fundamentally the same way causes him to neglect the problems with the chronology of the evidence and assume that the Titans and the anthropogony must always have been a part of the myth. Nevertheless, Detienne's analysis provides an insight into one of the levels of reinterpretation of the myth and explains why many of the details found in some versions-the boiling and roasting, perhaps even the presence of the Titans-were added by the teller.

53. Cf. Linforth 1941:328-29, contra Rohde 1925:353n. 28, on the combination of the two punishments as consistent. 
The motif of paying the penalty for the crimes of previous lives, which appears as early as Empedokles and the Pindar fragment (fr. 133), seems to be a development of the idea that descendants may have to pay the penalty for the crimes of their ancestors, an idea which has a long tradition in Greek mythology. Solon assures the wicked that even if they do not pay for their crimes in their

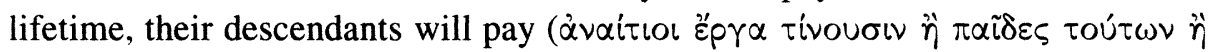

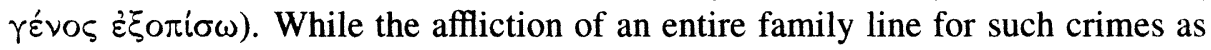
murder and perjury goes back to Homer and Hesiod, the myths of the punishment of an entire family as retribution for the murder of a family member, incest, or cannibalism become a favorite subject in tragedy. ${ }^{54}$ Nor is the family curse, in which each member must pay for the misdeed of an ancestor, confined to tragedy; this mythical idea was employed in practical politics as well. The prominent Athenian noble family of the Alcmaeonids, which boasted such members as Cleisthenes and Pericles, contended constantly with their political enemies about the stain that the murder of Cylon had left upon their family. ${ }^{55}$

Along with the idea of paying for an ancestor's crimes naturally comes the idea of somehow evading the penalty. Herodotus' myth of the fall of Croesus is fascinating in this regard: Croesus is doomed to fall, despite his many sacrifices to Apollo, because his ancestor Gyges murdered King Candaules and took his throne and his wife. When Croesus rebukes Apollo for ingratitude, Apollo informs him that his sacrifices were not ignored, but rather procured for him a three-year delay of the inevitable downfall. ${ }^{56}$ The Orpheotelests described in Plato's Republic seem to have promised more complete results from the sacrifices they advised, and, in the Phaedrus, Plato mentions Dionysiac purifications as bringing relief to those suffering under the burdens of the crimes of their ancestors. ${ }^{57}$ Olympiodorus refers to the role of Dionysos Lusios and his rites in freeing an individual from the penalty of crimes committed by ancestors. ${ }^{58}$ But, contrary to Graf's assertions

54. Solon fr. 1.31 , cf. esp. 25-35. Hereditary punishment of perjury: Il. 4.160-62, cf. 3.300ff.; Hesiod Op. 282-85. For affliction of whole families: Il. 6.200-205; Od. 20.66-78; cf. Od. 11.436. In tragedy: Aeschylus Sept. 653-55, 699-701, 720-91; Ag. 1090-97, 1186-97, 1309, 1338-42, 1460, 1468-88, 1497-1512, 1565-76, 1600-1602; Sophocles El. 504-15, Ant. 583-603, OC 367-70, 964-65, 1299; Euripides El. 699-746, 1306ff., IT 186-202, 987ff., Or. 811-18, 985-1012, 1546-48, Phoen. 379-82, 867-88, 1556-59, 1592-94, 1611. See further Parker 1983:191-206.

55. Cf. Hdt. 5.70-72; Thucydides 1.126-27. Noble families were not the only ones to feel the need of purification for their own crimes and those of their ancestors. Plato's Orpheotelests and the practices of Theophrastus' Superstitious Man indicate that individuals and whole cities tried to relieve their anxiety about the misdeeds of their forebears (Plato Rep. 364e-365a; Theophrastus Char. 16.12).

56. Herodotus 1.90-91.

57. Republic 364e-365a; Phaedrus 254de, 265b.

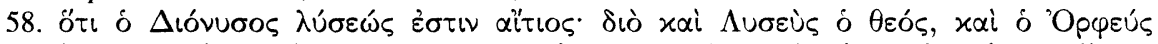

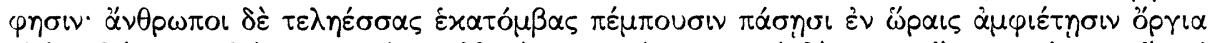

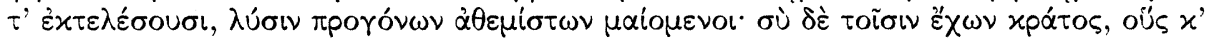

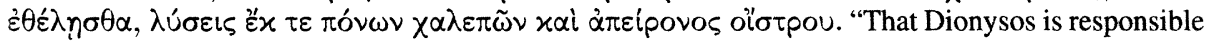
for release and because of this the god is called 'Deliverer.' And Orpheus says: 'People send perfect 
regarding the Pelinna tablets, the lawless ancestors of these passages need not be the Titans. Graf's hesitation betrays the flaw in his own argument: "But these ancestors are not just ordinary deceased, since Dionysus has power over them: the only ancestors of humans who are closely connected with Dionysus are the Titans, who killed the god-though it is somewhat unclear what power Dionysus has over them." ${ }^{59}$ Dionysos actually appears in quite a number of contexts as the deity who suspends the normal constraints, who bursts the bonds that regulate the order of the cosmos, providing relief for those constricted or burdened by the normal order. ${ }^{60}$ His role in freeing the initiate, in this life or the next, from the penalties due for the crimes of ancestors is simply an extension of this essential aspect to eschatology. ${ }^{61}$

The idea of a descendant's paying for an ancestor's crimes handles two difficult problems of theodicy: why some evil-doers are not visibly punished by the gods and why some apparently innocent folk suffer. In Empedokles and others who accepted a system of metempsychosis, the workings of justice are even neater, in that the delayed suffering falls not on some extension of the criminal in the form of a descendant, but on the individual himself in a later incarnation. In Empedokles, the cycle of reincarnations itself, the imprisoning of the soul in flesh, is a penalty for some crime of bloodshed committed as a divine being. For the prison of Tartaros or the waters of the Styx found in Hesiod as the punishment for divine beings who violate the order of Zeus, he substitutes the prison of the body. ${ }^{62}$ Centuries later, as we saw above, Plutarch explains Empedokles' adaptation of the tradition as a case of the ancient mythmakers concealing in riddling stories about the Titans the doctrine of reincarnation that Empedokles was putting forth as his own. Plutarch, perhaps following Xenokrates, thus links the strands of (1) sparagmos and (2) punishment, but he does not bring in the motif of (3) anthropogony, a general creation of the human race.

hecatombs in all seasons throughout the year and perform rites, seeking release from unlawful ancestors. But you, having power over them, you will release whomever you wish from harsh suffering and boundless frenzy'" (OF 232).

59. Graf 1993:244. Dionysos' power as Lusios, however, depends not on any special relation to the Titans as the criminals (or to the humans with a divine tidbit of Dionysos in them), but on his general function as the loosener, a trait illustrated even by the effects of wine, the most widespread symbol for the god.

60. For the role of Dionysos within polis-cult as the one who provides the necessary temporary relief from the normal order, cf. Sabbatucci 1979:51; cf. also Versnel 1991:139, 166, and Casadio 1987:199ff., on the functions of Dionysos Lusios.

61. Cf. the Pelinna tablets: "Tell Persephone that Bacchios himself has freed you" (

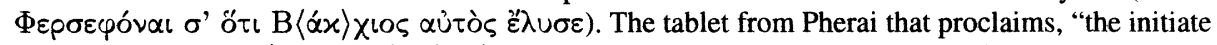

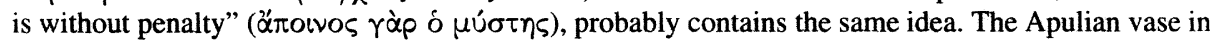
Toledo that depicts Dionysos greeting Pluto in the underworld seems to symbolize Dionysos' power to save his worshippers in the realm of the dead. (See Johnston and McNiven 1996.)

62. Empedokles B115 DK; cf. Seaford 1986, who traces the motifs of the imprisonment of a divine being from Hesiod through Empedokles, Herakleitos, and Aeschylus (although he assumes that the gold tablets provide evidence for the Titans imprisoned in human bodies). 
The Neoplatonic allegorical interpretation of the sparagmos of Dionysos may provide the link between the motif of dismemberment and the third strand in the tradition, the anthropogony. While there are many tales of the creation of certain human families, either autochthonously from the Earth or through the mating of mortals and gods, no story of the creation of the whole human race appears in the Greek tradition until the first century $\mathrm{CE} .{ }^{63}$ The idea that the Titans are the ancestors of all living creatures, however, is found as early as the Homeric Hymn to Apollo and recurs in a variety of mythical contexts. The Homeric Hymn to Apollo refers to the Titans as the ancestors of men and gods, while the Orphic Hymn to the Titans praises them as the ancestors of all living things. ${ }^{64}$ Dio Chrysostom's story of the creation of mankind from the blood of the Titans shed in their war against the gods links the creation of man to the story of the Titanomachy and thus to the idea of punishment. The gods persecute the race of men, Dio says, because men are descended from their enemies. ${ }^{65}$ Of all the testimonies to the myth, however, only the Neoplatonist Olympiodorus makes any kind of causal link between the punishment of the Titans for the dismemberment of Dionysos and the creation of mortal things from Titanic stock. ${ }^{66}$ Olympiodorus and other Neoplatonists see the myth of dismemberment as an allegory for the creation of the manifold material world out of divine unity by the action of the Titans, the forces of division. Thus, they could connect this myth with the anthropogonic myths, which also, in a fashion, make the Titans responsible for the existence of the diversity of mortal life. And even though some Neoplatonists combine all three mythic strands, weaving in the anthropogony with the motifs of the cannibalistic dismemberment and punishment, they still do not

63. Hesiod's myth of the metallic races (Op.106ff.) details the creation of several mortal races, but the myth describes the progressively worse conditions of life rather than providing an anthropogony for all mankind. The myth of the flood and the repopulation of the world by Deucalion and Pyrrha occurs first in Pindar (Olympian 9), but only in the much later Ovid (Met. 163-312) is it suggested that this episode begins the entire human race anew. Although this flood myth is conflated with the Biblical one by the early Christian Fathers, there is no reason to suppose it occupied the same prominence in Greek thought that Noah's flood did in the Biblical tradition. Plato's myth in the Protagoras (320-21) implies a creation of mankind, but it only details the gifts given to mankind by Prometheus.

64. Homeric Hymn to Apollo 334ff.; Orphic Hymn to the Titans (37).

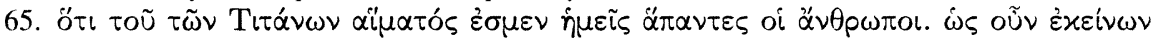

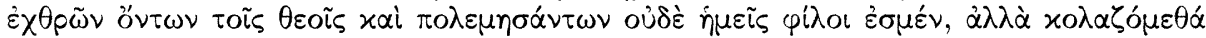

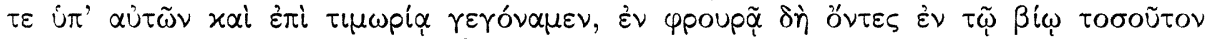

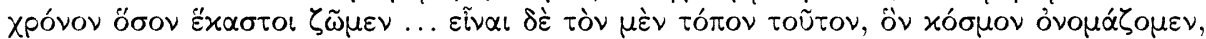

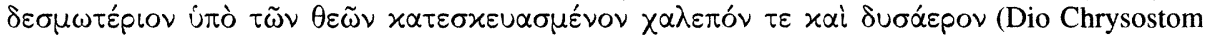
Or. 30.10-11). This text from the Second Sophistic attributes this gloomy view of life, with its echoes of the Platonic $\varphi p o u p \alpha$, to a morose man who must have suffered much in life. Oppian's Halieutica (5.1-10), on the other hand, which attributes the creation of man either to Prometheus or to the blood shed by the Titans in their war with the gods, attributes positive ramifications to the connection of humans to the Titans. The Orphic Argonautica (17ff.) links the race of mortals to the sperm of the Earthborn fallen from the sky.

66. Olympiodorus OF 220; cf. Proclus' version, which does not mention the dismemberment and probably implies the Titanomachy, OF 224. 
produce a doctrine of original sin. Even for these Neoplatonists, the myth of the dismembered Dionysos does not become the story of the Fall of Man, the central explanation of the degenerate state of the cosmos, but rather remains an allegory, a story told by the ancients who were so wise that they encoded Neoplatonic ideas in their myths.

Perhaps because the Neoplatonists too saw the myth as an expression of one of the fundamental principles of their ideology, the myth seems almost as popular among them as it is among modern scholars. However, just because the Neoplatonists cite the myth as evidence that the doctrine of the Many and the One was known to the ancients does not mean that we, like Rohde, should accept that this was always the meaning of the myth. Linforth notes, "In the age-long speculations on the problem of the One and the Many there is no record of the myth of the dismemberment before the Neoplatonists, and we have no right to say that because this allegorical application of the myth could have been made by its first author, it was so made." ${ }^{67}$ The myth no more referred to the Neoplatonic One and Many before the Neoplatonists than it referred to original sin before its interpretation by modern scholars. Although the parallel between the deaths and resurrections of Jesus and Dionysos was drawn by early Christian theologians such as Justinian and Origen, the idea that the Titans' murder of Dionysos was the original sin that caused mankind to need redemption does not appear-until Comparetti in $1879 .{ }^{68}$ The myth survived and remained popular precisely because it was susceptible to so many kinds of retellings and reinterpretations. The various tellers of the story used the different pieces of the myth-the motifs of sparagmos, punishment by lightning, Dionysos, the Titans, etc., etc.- to create versions of the myth that reflected the meaning they saw in it. Over many centuries, these bricoleurs assembled these pieces for their own purposes in numerous ways and have left a bewildering array of fragments of their tales behind.

\section{CONSTRUCTING AN ARTIFICIAL FRAME FOR THE PIECES OF ZAGREUS}

From this assortment of fragments, modern scholars constructed a picture of an "Orphic" religion, centered around the dismemberment of Dionysos by the Titans and the creation of mankind from their ashes, burdened with a kind of original sin. This picture remains appealing, even when the evidence on which it rests is shown to be flawed. Many scholars find the myth convincing despite their acceptance of the critique of the evidence. As Dodds comments, "Individually, these apparent references to the myth can at a pinch be explained away; but taking them together, I find it hard to resist the conclusion that the complete story was 
known to Plato and his public." ${ }^{69}$ Just the same six pieces of evidence, discussed in the first section, along with the passage from the gold tablets, underlie all of the arguments for the existence of the Orphic doctrine of the dual nature of mankind and the original sin inherited from the Titans, which modern scholars have seen as the natural product of the combination of the motifs of punishment and anthropogony. Other fragments provide testimony to other parts of the myth of Zagreus-the sparagmos of Dionysos, the cannibalistic feast, the punishment of the Titans, etc.-but the anthropogony and inherited guilt rest on these pieces alone. Why, then, were the anthropogony and subsequent doctrine of original sin made the crucial feature of Orphic religion and assumed to be the central point of the myth of Zagreus from its earliest tellings?

The answer, I would argue, lies in the role that Orphism played in the debates surrounding early Christianity in the scholarship of the late nineteenth and early twentieth centuries. The scholars of this period fit the same six pieces of evidence into the familiar models of Christian religious sects and put together a picture of Orphism as a religious sect, with a well-defined set of worshippers and religious doctrines. They used the "Orphic Church" thus created in the debates about the origin and nature of the early Christian church. These scholars were operating with a paradigm of religion that took as its model the familiar structure of the Christian religion, and this paradigm shaped the way they all imagined the religion they studied. Even Guthrie, perhaps the most careful and self-conscious about not applying a Christian model to the ancient religions he studied, admits, "We are brought up in an atmosphere of Christianity, and whether we like it or not, Christian notions of behaviour have sunk into the very marrow of our thought and expression." 70 The reconstruction of the Zagreus myth seems persuasive to scholars even today, despite the lack of evidence, because it resonates so thoroughly with this familiar paradigm of religion. In this section, I examine how Orphism was constructed as a kind of spiritual religious reform movement that foreshadowed the rise of Christianity, and I briefly sketch the ways in which this construction was used as a foil in the debates over the nature of the early church.

Orphism, as it was reconstructed by scholars in the late nineteenth and early twentieth centuries, was seen as a reform movement in Greek religion parallel to that of Protestantism in Christianity. This putatively purer, more rational, and more spiritual kind of religion paved the way for the coming of Christianity. Thus, Orphism was seen as a source or a parallel for many of the features that

69. Dodds 1951:156. The strength of the collection of evidence comes from the fact that it fits into the familiar paradigm.

70. Guthrie 1952:200. The extent to which he felt compelled to bow to the spirit of his times may be seen from his comment on the last page of his study on Orphism: "It is only from a feeling that a book on the Orphics which did not contain some comparison with the Christians would probably be thought intolerable, that I have been persuaded to depart even so far from the principle that the study here attempted is not a comparative one" (Guthrie 1952:271). 
distinguished Christianity from other mystery religions of the period. Scholars constructed Orphism as an advanced, spiritual religion in accordance with the dominant paradigm of religion at the time, a model shared not only by scholars of a Protestant bent but also by anticlerical movements within the Catholic church. In this model, a good and advanced religion was characterized by an emphasis on personal and individual spirituality rather than the performance of traditional ritual, an absence of priestly hierarchy linked with state political control, and a rational and sophisticated theology grounded in the exegesis of sacred texts. Moreover, the content of the religious beliefs should focus on the fallen nature of mankind and its redemption through divine action.

As J. Z. Smith has argued in his Drudgery Divine, this model of what a good religion should be, often expressed in terms of the contrast between medieval Catholicism and the Protestant Reformation, influenced the reconstruction of the mystery cults that were contemporary with early Christianity. The early Christian church was seen as pure and spiritual like the Protestant church, in contrast to the mystery religions whose ritual and ceremonial focus made them more like the Catholic church:

This is a modulation of the Protestant historiographic myth: a "uniquely" pristine "original" Christianity which suffered later corruptions. In this construction one is not, in fact, comparing early Christianity and the religions of Late Antiquity. The latter have become code-words for Roman Catholicism and it is the Protestant catalogue of the central characteristics of Catholicism, from which it dissents, which provides the categories for comparison with Late Antiquity. ${ }^{71}$

To a certain extent, the mystery cults were reconstructed by these scholars to fit the arguments, becoming the sources of the corruption of the pure early Church that led to the development of Catholicism. As Smith points out, the evidence for these mystery cults was often distorted in the attempt to find the sources and parallels for the negative elements in Catholicism, with the result that the mystery religions were often depicted as largely focused on ritual and ceremony at the expense of spiritual content and dominated by priestly hierarchies rather than personal contact with the divine.

A similar distortion of the evidence occurred in the scholarship on Orphism, although Orphism was more often cast in the mold of the "good" type of religion. Comparetti, whose interpretation of the gold tablets in terms of an alleged Orphism centered around a doctrine of original sin set the terms for the modern reconstruction of Orphism, has been noted for his anti-clericalism. As Ziolkowski describes it, "One aspect of Comparetti's conflicted outlook on Christianity has been called 'rationalist laicism': a predisposition to accentuate those beliefs and 
practices of medieval Christianity that appeared to be adaptations of paganism."”2 Comparetti and the scholars who followed his interpretation of the tablets saw Orphism as more advanced than the other religions of its time, more like their model of a "good" religion. Accordingly, they saw in Orphism the familiar characteristics of religion as they knew it: a founding prophet, a sacred scripture, and a developed rational theology. At the center of such a religion must be a doctrine of the redemption of mankind through the suffering and death of the divine savior, for only such a doctrine could provide a truly religious understanding of the world. Zagreus was the perfect candidate for the suffering savior, and Olympiodorus' story of the birth of mankind from the Titans suggested, to Comparetti and later scholars, an origin for the fallen nature of mankind, the source of original sin as well as the hope of redemption.

Like Protestantism, Orphism was described as, in essence, a reform movement, although the nature of the reform depends upon the scholar. Harrison saw Orpheus as the prophet of a reform of the primitive, ecstatic Dionysiac religion. She displays her own sympathies in describing a picture of the death of Orpheus at the hands of the maenads: "Orpheus was a reformer, a protestant; there is always about him a touch of the reformer's priggishness; it is impossible not to sympathize a little with the determined looking Maenad who is coming up behind to put a stop to all this sun-watching and lyre-playing." ${ }^{\text {,73 }}$ Macchioro makes the comparison between Orphism and Protestantism explicit: "The links between the Dionysiac religion and Orphism might be aptly compared with the links which exist between a religion and its sects; for instance, between Christianity and Lutheranism. In other words, I think that Orphism was a particular branch of Dionysiac religion centering around the person and the activity of a reformer, which in time reached the importance and the diffusion of a really new religion." ${ }^{74}$

Others see Orphism as a reform of traditional Greek (that is, Homeric) religion. Watmough's entire essay is devoted to the parallels between Homeric religion and Orphism on the one hand and the medieval Catholic Church and Protestantism on the other:

In the ancient world we have the religion of Homer, entirely concerned with sacrifice and ritual, entirely dominated by the note of "Confiteor"the confession of vows duly performed: and over against it the religion of "Orpheus," which emphasised the relation of the individual soul with God, for authority turning not to priests but scriptures. In the more modern world we have the mediaeval Church, a picturesque and colourful religious system based on sacerdotalism and ecclesiolatry: over

72. Ziolkowski 1997:xxviii. That the Jesuit-educated Comparetti combined his anti-clericalism with a strong Italian nationalist bent hints at the complexities of these debates about the nature of the early Church.

73. Harrison 1922:461.

74. Macchioro 1930:137. 
against it the Protestant reformers with their "justification by faith" and bibliolatrous attitude to the canonical writings. ${ }^{75}$

The Orphic reform, according to these scholars, spiritualized the meaningless rituals of traditional religion and gave them a significance for the individual in his relations with the divine, just as the Protestant Reformation did away with the ritualism of the Catholic Church and focused on the relation of the individual with God. Of the rituals of Homeric religion, Watmough claims, "The important fact is that they were devoid of moral and spiritual significance. With 'Orphism' much of the ritualistic and ceremonial element is retained, but behind there is much more real and much more personal yearning to escape from an abstract power called Evil.... The parallel in modern Protestantism is clear to the most superficial observer."76 Orphism even surpasses the other mystery religions with this emphasis on the personal and spiritual rather than ritual and ceremonial elements. Morford and Lenardon compare Orphism with the most famous of the mystery cults, the Eleusinian Mysteries: "The mysteries of Demeter, with their emphasis on participation in certain dramatic rites, lacked the spiritual depth of Orphism with its insistence on the good life as well as mere initiation and ritual." 77

The point of all these comparisons is that Orphism is higher up on the scale of religions than the other forms of Greek religion (be it Dionysism, Homeric cult or the other mystery cults), just as, for the same reasons, Protestantism (or a reformed version of modern Catholicism) is higher than medieval Catholicism. Protestantism was thus mapped onto another of the dominant paradigms of the day, the idea of the evolution of mankind in terms of a growing rationality and individuation. As Orphism represents an advance on the other forms of Greek religion, so Christianity represents an advance on the earlier Greek religions, and so too Protestantism represents an advance over medieval Catholicism in terms of rational theology for the individual. Macchioro explicitly posits an evolutionary scale of religions, progressing from the childishly irrational to the maturely reasonable and spiritual: "Human spiritual evolution progresses from a maximum to a minimum of imagination. It seems that the path of history leads mankind from fantasy to reason, from a mythical to a logical condition. Perhaps progress consists in getting rid of that overwhelming power of fantasy, which seems to dominate children and primitive people." ${ }^{78}$ Orphism is thus for Macchioro the step on the road from pagan myth to Christian religion. ${ }^{79}$

This construction of Orphism served in the debates about the nature of early Christianity as a foil to the mystery cults and other forms of Greek religion. Just as

75. Watmough 1934:56-57.

76. Watmough 1934:50.

77. Morford and Lenardon 1999:280-81.

78. Macchioro 1930:73.

79. Literally. Macchioro argues, in a number of his books, that St. Paul was directly influenced by Orphism in his theology. 
early Christianity was being constructed as a kind of pure anticlerical Christianity that was superior to the contemporary mystery cults and the later Catholic Church, so Orphism was constructed as a kind of Protestant reform movement in contrast with Homeric religion, Dionysism, or other mystery cults. Orphism thus became a forerunner of Christianity, a vehicle for the best parts of Greek culture-the rational, spiritual, philosophical, Apollonian parts. ${ }^{80}$

Orphism was depicted as a movement ahead of its time, an enlightened religious movement in the midst of pagan superstitions. As such, Orphism must be given the familiar features of an advanced, enlightened religion. Macchioro distinguishes between spontaneous religions, in which he includes all "primitive" religions, and revealed, doctrinal religions. "The spontaneous religions which do not boast of a founder at all, are the outgrowth of primitive, unconscious, religious needs, which were never shaped into any rigid definite schema. Herein lies the explanation of the overwhelming power exerted by the imagination in these religions, and, conversely, of their theoretical and philosophical poverty." 81 Orphism he firmly classifies with the revealed religions like Judaism, Christianity, and Islam, since it has all the requisite features: a founding prophet, a sacred scripture, and a developed, rational theology.

According to this reconstruction, the founding prophet of Orphism is, of course, the mythical poet Orpheus, who, like a good Biblical prophet, was not without honor except in his own country of Thrace. In Thrace, he was torn apart by maenads, a martyr to the spiritual religion he came to preach to the savage primitives. The historicity of Orpheus himself was debated among these scholars, but the historical kernel was rarely doubted. As Harrison says, "The blood of some real martyr may have been the seed of the new Orphic church." 82 The prophet set forth in his poetry the doctrines of his new religion, as Morford and Lenardon tell us: "Orpheus was considered the founder of a religion, a prophet (theologos) who with his priests and disciples committed to writing holy words (hieroi logoi) that provided a bible for dogma, ritual, and behavior." 83 In keeping with the familiar model of Protestant religion centered around the exegesis of the sacred scripture, the poetry of Orpheus is seen by these scholars as the equivalent of the "Orphic Bible."

80. The Nietzschean contrast between the Dionysian and the Apollonian plays a part in this story of the myth of Zagreus, largely because of the influence of Nietzsche's friend Rohde, who described Orphism as a reform of Dionysiac religion, a movement tending to the rational and philosophical Apollonian facet of Greek culture. The story of Orpheus' death at the hands of Maenads angered by his devotion to the Sun (identified with Apollo), a story extrapolated from a scholiast's reference to Aeschylus' lost Bassarai, became the central symbol of the Apollonian/Dionysiac tension within Orphism.

81. Macchioro 1930:123-24.

82. Harrison 1922:468. Cf. Nilsson, contra Kern (Orpheus 26 [Berlin, 1920]): "I should not dare to say that Orpheus died a martyr to his religion, but his manner of death is the mythical vengeance for his blasphemy according to the jus talionis" (Nilsson 1935:204).

83. Morford and Lenardon 1999:278. 
This idea of the Orphic sacred scriptures played an important part in the fabrication of a proto-Protestant Orphism. Numerous titles of works said to be by Orpheus have been preserved in the commentators of late antiquity. In the Classical period, Plato and Euripides both refer to collections of writings by Orpheus. ${ }^{84}$ Since mainstream Greek religion had no sacred writings at all, the Orphics, defined as those who use works by Orpheus, seem, by contrast, to be much more like a familiar religion of the Book. Guthrie draws an exaggerated conclusion from this importance of writing in Orphism, "The Orphic did nothing unless there was a warrant for it in his books." ${ }^{85}$ Of course, the reasoning here is somewhat circular. Since the "Orphics" are defined as those who refer to the writings of Orpheus, the writings become, by definition, the central defining feature of the group.

This idea of the importance of scripture for the Orphics seems to persist even in West's recent assumption, never defended, that the details from the late Rhapsodic Theogony must come from earlier, complete theogonies, rather than from shorter works that included theogonic material, perhaps, e.g., the other Orphica whose titles are preserved in various sources. West assumes that the sources of the later Orphica were comprehensive stories of the creation of the world, the gods, and mankind (on the scale of Hesiod's Theogony or perhaps Genesis) that provided a complete and consistent theological framework for everything. West gives no argument or evidence for this assumption; indeed, the extant evidence would seem to tell against such an assumption. The only theogony that actually survives, the theogony commented upon in the Derveni papyrus, is not a comprehensive theogony. Therefore, West claims, it must be an abridgment of a comprehensive, but not extant, theogony, which he calls the Protogonos Theogony. ${ }^{86}$

The assumption that the Orphic theogonies must have been comprehensive accounts seems to rest on the idea that these "Orphics" relied on these poems as sacred scripture from which they derived their religious doctrine. The reasoning seems to run something like this: since they derived all their doctrines from the scriptures, the scriptures must be complete and comprehensive, providing a warrant for every feature of their religious life. Rohde indeed marks this as a trait which distinguished the Orphics from the rest of Greek religion: "The Orphic sect had a fixed and definite set of doctrines; this alone sufficed to distinguish it both from the official worships of the state, and from all other cult-associations of the time. The reduction of belief to distinct doctrinal formulae may have done

84. Euripides Hippolytus $(943-57=$ OT 213): Theseus refers to Orphics with their $\pi 0 \lambda \lambda \hat{\omega} \nu$

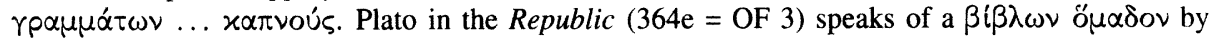
Orpheus and Musaeus (in Dodd's felicitous translation, "a hubbub of books"). Pausanias (1.37.4 = OT 219) seems to draw a distinction between the rites of Eleusis and the Orphic writings, but this does not necessarily imply that Orphism was solely or even primarily a literary tradition.

85. Guthrie 1952:202.

86. West 1983:69, 101. 
more than anything else to make Orphism a society of believers." ${ }^{87}$ The Orphics were thus characterized as a religious sect that derived a sophisticated theology from their comprehensive cosmogonic myths. Or, to look at it from the other side, the Orphics developed comprehensive cosmogonies because of their rationalistic interest in philosophical theology. Macchioro goes so far as to claim that the Orphics really had very little myth, but a great deal of philosophical, theological speculation:

In the last analysis, Orphism had no mythology of its own, with the exception of a few theological accounts and tales, such as the description of the world of the dead, and some cosmogonies; otherwise nothing to compare with the enormous richness of Greek mythology. This lack of mythical interest is offset by a living interest in theological and cosmological problems, as is shown by the very great antiquity of Orphic theogonies and cosmogonies, and their tendency to generate philosophies. ${ }^{88}$

In other words, the only myths of the Orphics were stories on real theological concerns, such as creation, eschatology, and soteriology. ${ }^{89}$ According to these turn-of-the-century scholars, Orphism-with its founding prophet, sacred scriptures, and sophisticated theology-was far advanced on the road from mythos to logos, from pagan superstition to enlightened religion.

At the center of this proto-Christian Orphism, scholars naturally looked for a parallel with the death and resurrection of Christ, with an attendant doctrine of redemption from original sin as a consequence of his passion. The myth of Zagreus seemed to include the death and resurrection of a god, and, with the anthropogony in the version of Olympiodorus, the possibility for a doctrine of original sin. As a result, scholars made it the heart of their reconstructed Orphism. "We come now," Guthrie says, "to what must have been for a worshipper the central point of Orphic story, the tales of Dionysos son of Zeus and his sufferings." "There is no doubt," asserts Macchioro, "that the death and resurrection of Zagreus formed the pivot of the whole Orphic mystery." 91 The myth of Zagreus is seen by these scholars as the story which provides the meaning of the whole religion, much as the story of Christ provides the religious meaning for Christianity.

But a mere story of death and resurrection would be insufficient, in the light of Frazer and his examples of dying and rising gods all over the Mediterranean. The anthropogony attached to the myth provides the necessary connection with mankind to give the myth the kind of religious significance that the resurrection of

87. Rohde 1925:338. For "the official worships of the state" we may understand "Catholicism"; for "all other cult-associations of the time" we may understand "the mystery cults."

88. Macchioro 1930:129.

89. Cf. Smith, "In the hands of many scholars, both past and present, it is primarily soteriological notions which supply an evolutionary scale that ranks religions, with Protestant Christianity often serving as the implicit or explicit norm or the culmination of the exercise" (Smith 1990:119).

90. Guthrie 1952:107.

91. Macchioro 1930:75. 
Christ has in Christianity. Only the anthropogony could make the myth of Zagreus about sin and redemption, and therefore, scholars concluded, it must always have been part of the story central to this religion. Guthrie identifies this story as the crucial feature that permits Orphic poetry, unlike the traditional theogony of Hesiod, to become the basis for a truly religious life:

There is no Chronos in Hesiod, none of the curious second beginning of all things within the body of Zeus, above all none of the story of Dionysos and the Titans. From this it follows that the human interest with which the Orphic poem ends is entirely lacking in Hesiod, and his theogony is divorced from ideas of good and evil .... In short, the fundamental difference between the two systems lies here: the one could never be made the doctrinal basis of a religious life; the other both could be and in fact was. ${ }^{92}$

Human interest comes from the anthropogony, which makes the myth about the salvation of mankind rather than simply a tale of long ago. Nilsson explicitly draws this distinction between myths, which tell fantastic tales without any religious significance, and the anthropogonic myth of the Orphics, which, because it is about sin and redemption, has a truly religious significance: "Beginning with Chaos and ending with the creation of man the cosmogony is rounded off into a systematic whole which has not only a mythical but also a religious meaning. Its final aim is not to relate tales of the world and of the gods, but to explain the composite nature of man and his fate." ${ }^{93}$ Traditional Greek cult, in other words, had only myths; the Orphics had a real religion. ${ }^{94}$ The crucial significance of the anthropogony to the picture of Orphism as a kind of proto-Christian religion explains why so many scholars insist on its presence from the earliest tellings of the story, despite the lack of any solid evidence. ${ }^{95}$

The placement of the Zagreus myth with its anthropogony at the heart of Orphism from its inception depends, then, on the model of Orphism as a kind

92. Guthrie 1952:84.

93. Nilsson 1935:225 (my emphasis).

94. Rohde too makes the distinction between myth and real religion. "The myth of the dismemberment of Zagreus by the Titans was already put into verse by Onomakritos; it continued to be the culminating point of the doctrinal poetry of the Orphics.... It is a religious myth in the stricter sense; its aetiological character is most marked" (Rohde 1925:341). Cf.: "This poem must have been one of the basic, and in the strictest sense 'religious' [im engeren Sinne religiöse] writings of the sect" (Rohde 1925:338).

95. West, in his recent treatment of the Orphic poems, places the Zagreus myth and the anthropogony together in what he calls the Eudemian theogony, the second oldest of the Orphic theogonies he identifies (West 1983:140-75). Although he accepts the arguments of Linforth 1941 regarding the evidence, he nevertheless assumes that the anthropogony and doctrine of Titanic guilt must have been part of the myth of the murder of Dionysos Zagreus, which he links to Cretan initiation rituals. West here seems to ignore the consequences of Linforth's conclusions; he accepts the doctrine of Orphic original sin and salvation left over from the turn-of-the-century paradigm of religion without questioning and works it into his reconstruction wherever he can make it fit. 
of proto-Protestantism, a real religion according to the paradigm of religion used by the scholars, both Catholic and Protestant, at the end of the nineteenth and beginning of the twentieth century. This paradigm of religion continues to be influential, which is why the reconstruction of the Zagreus myth from the fragments of evidence continues to be persuasive. Such a model of religion, however, distorts the evidence, taking the fragments out of their proper context and placing them in an alien and artificial structure. The apparent coherence of the evidence comes only from our familiarity with the structure in which they are placed. The myth of Zagreus, which brings together the ancient tales of the dismemberment of Dionysos and the punishment of the Titans, the later tales of the creation of mankind, and the idea of original sin and redemption borrowed from the modern Christian ideas of religion, is a fabrication of the scholars of the late nineteenth and early twentieth centuries.

\section{REPLACING THE HEART OF THE ZAGREUS MYTH}

This modern myth of Zagreus arose from the discovery of the gold tablets at Thurii in 1879, a set of cryptic and fragmentary texts that forced scholars to reexamine the old evidence for Greek religious beliefs. Comparetti's interpretation of the newly discovered Thurii tablets in terms of an Orphic doctrine of original $\sin$ (based on the anthropogony found in Olympiodorus) laid the foundation for the reconstruction of Orphism in the early twentieth century. Although scholars have begun to discard this outdated model for understanding Orphism as a whole, the interpretation of the tablets themselves still rests largely on the central feature of this turn-of-the-century paradigm, the myth of Zagreus. ${ }^{96}$ However, just as I have shown that the various tales of Dionysos' dismemberment can be understood with reference to ideas for which there is evidence within the Greek religious tradition, so too the Orphic gold tablets must be interpreted apart from this anachronistic myth. The imagery of the gold tablets draws on a variety of mythical elements familiar from the mythic tradition, but the resonance of each of these elements is lost if they are all read as referring to a single myth of anthropogony and original sin, a myth not told until 1879 , thousands of years after the tablets were composed. By examining the claims of the gold tablets without the framework of the Zagreus myth, we can make better sense of the religious traditions and

96. Burkert is among the few moving beyond the old paradigm. In Greek Religion he suggests, "Once again this is not to say that all forms of Bacchic mysteries are built on this foundation. When the dead man of Thurioi introduces himself as the 'son of earth and starry heaven' [sic], the myth of the Titans is not necessarily implied; the 'penance for unjust deeds' on the Thurioi leaves might be better grouped with Pindar and Plato" (Burkert 1985:298). The fact that even Burkert conflates the A tablets of Thurii (which mention penance and lightning) with the reference to the "child of earth and starry heaven" in the B series (which mention neither penance nor lightning) shows the lingering influence of the model which lumped all of the tablets into a single category that was interpreted through the Zagreus myth. 
the individual groups that produced the tablets. A brief analysis of some of the statements on the tablet from Thurii quoted at the beginning of this essay may serve as a demonstration.

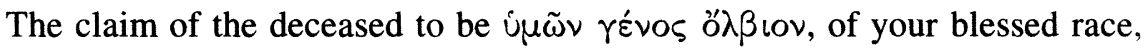
when addressing a deity is by no means impossible for a mortal outside the framework of the Zagreus anthropogony. As mainstream a poet as Hesiod says he will tell how the gods and man came from the same origin, $\omega_{\zeta} \delta \mu o ́ \theta \varepsilon \nu ~ \gamma \varepsilon \gamma \alpha \dot{\alpha} \alpha \sigma$ เ

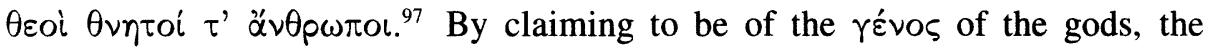
deceased is employing a familiar mythic element to make a claim that transcends the clan politics of her contemporary world, where status is based on family position and the confinements of various social hierarchies. The deceased instead lays claim to kinship with the gods, recalling the ideal of the time before the separation of mortals and immortals. Hesiod's description of the unity of men and gods, which ended with the divisive sacrifice at Mekone, is only the most obvious of the numerous myths of an idealized primeval communion of men and gods. ${ }^{98}$

The deceased also claims to have paid the penalty for unjust deeds. These unjust deeds may either be those of the deceased herself or those committed by some ancestor, as Plato's discussion of purificatory rituals for unjust deeds in the Republic shows: "For beggar priests and prophets go to the doors of the rich and persuade them that they have the power from the gods to perform sacrifices and spells. If they or one of their ancestors has done something unjust, they have the power to heal it with pleasurable things and festivals." ${ }^{99}$ But Plato's discussion also shows that these ancestors are unlikely to be the Titans as the universal ancestors of mankind, for every mortal has ancestors who were less than perfectly just. The use of this mythic element in the tablets would have evoked a wide range of traditional stories of individuals paying the penalty not only for their own crimes, but for those of their ancestors.

The claim of the deceased to have been struck by lightning also admits of more interpretations than the punishment of the Titans, for the idea has a number of interesting mythic resonances. The Titans were by no means the only

97. Hesiod Op. 108. Closer to these tablets in time and place, Pindar begins the Sixth Nemean

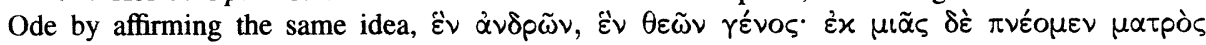
$\alpha \mu \varphi$ ó $\varepsilon$ pol (1-2). A different formulation of the same idea may be found in the B tablets' formula of self-identification, "I am the child of earth and starry heaven," a Hesiodic phrase that would apply not only to the Titans but to all of the later generations of gods (and possibly mortals). Cf., Hesiod Theog. 105-106.

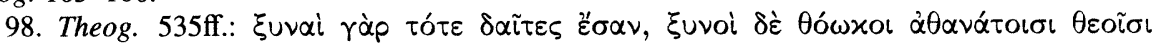

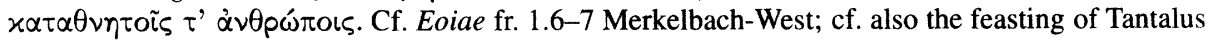
and Ixion with the gods.

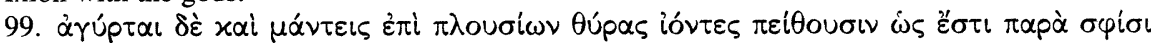

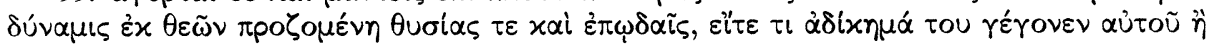

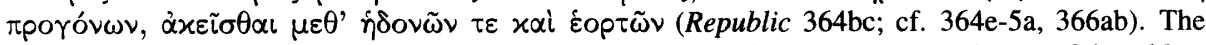
other tablets from Thurii, A1 and A4, make no mention of paying a penalty, nor do any of the tablets in the B series. The Pelinna tablets refer to Bacchios freeing the initiate, perhaps meaning that she, like the initiate of the Pherai tablet, need not pay a penalty. 
ones to have felt Zeus' lightning bolt. Apart from other monstrous enemies of Zeus, like Typhon, a number of heroes were struck by lightning in a variety of myths. As Rohde states in his Appendix on the "Consecration of Persons Struck by Lightning," "In many legends death by lightning makes the victim holy and raises him to godlike (everlasting) life." 100 In some versions, Herakles' apotheosis upon the pyre at Oeta was accomplished by Zeus' thunderbolt, and Semele and Asclepius, for example, were also struck by lightning before their final apotheosis or heroization. ${ }^{101}$

These three examples are particularly interesting because each of these heroes could better serve as the mythic reference for the gold tablets than the Titans. Each of them was originally a mortal, but divinely descended or connected; each committed unjust deeds; and each was described as being hit by the lightning of Zeus. For Herakles, the lightning strike was strictly part of the apotheosis or heroization process rather than punishment, but for both Asclepius and Semele the lightning bolt served as the punishment for the unjust deeds, with the apotheosis or heroization following. The use of the mythic element of the lightning strike in the tablets would conjure up the tales about these heroes and confer some of the authority of these tales upon the deceased's account of herself, as well as transferring some of the prestige of these figures to the deceased. The deceased did not necessarily see herself as another Semele or even another Herakles, but rather these figures served as the mythic precedents, having undergone the same process of heroization, of purification through the fire of the lightning bolt, which simultaneously stripped them of their mortal impurities and translated them to the realm of the immortals.

Such explanations of the verses on the gold tablet may not tidily explain the religious ideas behind the tablet in terms of a single, central myth that provides the doctrine for the cult, but they do point to a kind of bricolage of mythic ideas drawn from a set of beliefs and ideas found elsewhere in Greek religion. Our knowledge of the rich tradition from which these elements were drawn remains fragmentary, but the careful reconstruction of the contexts and meanings of such fragments as the gold tablets deepens our understanding of the tradition and how it was used. Such a reconstruction, whether it be of the religious background of the gold tablets or of the various uses of the myth of Dionysos' dismemberment is, of course, more difficult than simply squeezing them all into the framework of a single myth, and the end product is less satisfyingly neat. Alister Cameron, in his 1942 review of Linforth, complains, "Linforth's analysis of these texts

100. Rohde 1925:581-82.

101. Herakles: D.S. 4.38.4-5. Semele: Pind. O. 2.27; D.S. 5.52.2; Charax ap. Anon. de Incred. xvi; Arist. 1, p. 47 Dind.; Philostr. Imag. 1.14; Nonnos Dion. 8.409ff. Asclepius: Hesiod fr. 109 Rz.; Lucian DD. 13. Cf. also figures such as Erectheus, Kapaneus, and Amphiaraus. The sacralizing effect of lightning may been seen from later testimonies in the reverence for the lightning-struck tombs of Lycurgus and Euripides in Plut. Lyc. 31 and Pliny's report that the thunderbolting of the statues of Olympic victor Euthymos indicated his heroic status (NH 7.152). 
fractures their unity and gives us back a structure of unsatisfactorily assembled fragments." 102 Such a messy picture was unacceptable in Linforth's day, and, as a result, Linforth's analyses have been ignored and their consequences have not been pursued. The picture of Orphism and the myth of Zagreus that emerges from a careful analysis of the evidence lacks the neat and unified outline presented by the reconstruction in terms of a doctrine of original sin and a proto-Protestant sect. The evidence is less distorted, however, because it is not all crammed into a single framework. I have given some tentative suggestions about the ways in which the evidence may be seen to reflect the retellings of the dismemberment myth over time and the ways in which the gold tablets might be interpreted, but such outlines could certainly be further fleshed out.

\section{CONCLUSION: BURYING THE REMAINS}

I shall have to traverse ground which has been churned to deep and slippery mud by the heavy feet of contending scholars; ground, also, where those in a hurry are liable to trip over the partially decayed remains of dead theories that have not yet been decently interred. We shall be wise, then, to move slowly, and to pick our steps rather carefully among the litter. $^{103}$

Dodds' warning about the perils of research on Orphism remains apt, and since his time the mud has been further churned and more theories have slipped into ruin, leaving behind their partially decayed remains. One such relic that continues to trip up the passerby is the myth of Zagreus, left over from the proto-Protestant model of Orphism that dominated the scholarship in the first half of this century. It is time that it be decently laid to rest.

Morford and Lenardon's introductory textbook, with its version of the Zagreus myth from "the Orphic bible," 104 is hardly alone in perpetuating this error. The standard references for the professional classicist are no better, and in most cases worse, since most have not been updated since the forties or fifties. The PaulyWissowa article on Orphism and the Roscher Lexicon of Mythology on Zagreus, just to name two of the most prominent, both contain accounts of the Zagreus myth that place it at the center of the Orphic puritans' doctrine of original sin. ${ }^{105}$ The most recent works by the experts on the subject are beginning to lean towards

102. Cameron 1942:458.

103. Dodds 1951:136.

104. Morford and Lenardon 1999:280.

105. Ziegler in P-W, cols. 1354, 1381-82; Schmidt in Roscher, vol. VI, col. 535. Cf. Dodds' assessment of the Pauly-Wissowa article: "A spirited counter-attack on this 'reactionary' scepticism was delivered in 1942 by Ziegler, representing the Old Guard of pan-Orphists, in the guise of an article in a work of reference" (Dodds 1951:168, n. 79). Even the new (1996) Oxford Classical Dictionary entry by Fritz Graf includes the Zagreus myth as the centerpiece of Orphic literature (OCD s.v. Orphic literature). 
the abolishment of the old Zagreus myth, but the qualified statements of such scholars as Burkert, Graf, and West do not go far enough. West, for example, removes the Zagreus myth from the earliest of Orphic theogonies and accepts (in his footnotes, if not in the main text) most of the arguments of Linforth regarding the evidence. Nevertheless, he places the story in the second oldest theogony and continues to give it pride of place in Orphic doctrine. "According to the Eudemian Theogony, on the other hand, mankind came into being from the soot deposited by the smoke from the blasted Titans. This must have been given as a reason why we are sinful creatures who must seek salvation through purification." 106

Burkert, followed by others, has begun to reconstruct the evidence for Orphism according to paradigms of religion different from the standard Christian model used at the turn of the century. These scholars recognize Orphism as a modern term to describe a range of counter-cultural religious movements which frequently attributed their religious ideas to the authority of the mythical poet Orpheus. ${ }^{107}$ As a result, these scholars have begun to de-emphasize the importance of the Zagreus myth in Orphic and Dionysiac mythology. Burkert cautiously admits that, "as for Dionysos, there is a rich variety of Bacchic mythology, but with regard to mysteries one tale has commanded attention, perhaps too exclusively: the story of Chthonian Dionysus born from Persephone and slaughtered by the Titans, ancestors of man." 108 This relic of an outdated paradigm has done more than simply command undue attention; it has obstructed the understanding of ancient Greek Orphism, because it was used to define the essence of Orphism. Despite the recent shift in the scholarship, the Zagreus myth persists, particularly in the interpretation of the original cornerstone of the reconstructed Orphism, the "Orphic" gold tablets. This myth of Zagreus must be torn apart, and the fragments of evidence collected and restored to their context so that the various uses and metamorphoses of the Greek myth of Dionysos may be recovered.

University of Chicago rgedmond@midway.uchicago.edu

\section{BIBLIOGRAPHY}

106. West 1983:246. He lists this myth as one of the two major contributions of Orphism to Greek religion. "Its mythology was not exclusive to it, though it did provide the main channel of transmission for two major myths, the Time-cosmogony and the murder of Dionysus by the Titans" (West 1983:263).

107. Cf. West, "It is a fallacy to suppose that all 'Orphic' poems and rituals are related to each other or that they are to be interpreted as different manifestations of a single religious movement.... There was no doctrinal criterion for ascription to Orpheus, and no copyright restriction. It was a device for conferring antiquity and authority upon a text that stood in need of them" (West 1983:3). See also: Burkert 1975, 1977, 1982; Detienne 1975; Redfield 1991; Sabbatucci 1975, 1979. The OCD article by Graf on Orphism follows this trend as well.

108. Burkert 1987:73. 
Alderink, L. 1981. Creation and Salvation in Ancient Orphism. American Classical Studies 8. Chico, Calif.

Berthelot, M. 1888. Collection des anciens alchimistes grecs. Paris.

Bianchi, U. 1966. "Pêché originel et pêché 'antécédent.'" Revue de l'histoire des religions 170: 119-26.

Boyancé, P. 1963. “Note sur la ФPOҮPA platonicienne.” Revue de philologie 37: 7-11.

Brisson, L. 1985. "Les théogonies orphiques et le papyrus de Derveni." Revue de l'histoire des religions 202: 389-420.

. 1992. "Le corps 'dionysiaque.' L'anthropogonie décrite dans le Commentaire sur le Phédon de Platon (1, par. 3-6) attribué à Olympiodore est-elle orphique?" In $\Sigma O \Phi I H \Sigma$ MAIHTOPE $\Sigma$ / Chercheurs de Sagesse: Hommage à Jean Pepin, Institut d'Études Augustiniennes, 483-99. Paris.

. 1995. Orphée et l'orphisme dans l'antiquité gréco-romaine. Variorum Collected Studies Series. Brookfield, Vt.

Burkert, W. 1975. "Le laminette aurée: Da Orfeo a Lampone." In Orfismo in Magna Grecia: Atti del quattordicesimo convegno di studi sulla Magna Grecia, 81-104. Napoli.

. 1977. "Orphism and Bacchic Mysteries: New Evidence and Old Problems of Interpretation." In Protocol for the Center for Hermeneutical Studies in Hellenistic and Modern Culture: Colloquy 28: 1-10.

. 1982. "Craft Versus Sect: The Problem of Orphics and Pythagoreans." In B. F. Meyer and E. P. Sanders, eds., Jewish and Christian Self-Definition, vol. 3, 1-22. London.

- 1985. Greek Religion: Archaic and Classical. Trans. J. Raffan. Oxford.

- 1987. Ancient Mystery Cults. Cambridge, Mass.

Cameron, A. 1942. "Review of The Arts of Orpheus by Ivan M. Linforth." AJA: 455-60.

Casadio, G. 1986. "Adversaria Orphica et Orientalia." Studi e materiali di storia delle religioni 52: 291-322.

- 1987. "Antropologia orfico-dionisiaca nel culto di Tebe, Corinto e Sicione." In F. Vattioni, ed., Sangue e Antropologia: Riti e Culto, 191-260. Roma.

Comparetti, D. 1879, 1880. In F. S. Cavallari, Notizie degli Scavi, 1879: 156ff., 1880: $152 \mathrm{ff}$.

. 1882. "The Petelia Gold Tablet." JHS 3: 111-18.

. 1910. Laminette Orfiche. Firenze.

Creuzer, F. 1822. Symbolik und Mythologie der alten Völker besonders der Griechen. Leipzig and Darmstadt.

Detienne, M. 1975. "Les chemins de la déviance: Orphisme, dionysisme et pythagorisme." In Orfismo in Magna Grecia: Atti del quattordicesimo convegno di studi sulla Magna Grecia, 49-79. Napoli.

- 1979. Dionysos Slain. Trans. M. and L. Muellner. Baltimore.

Dieterich, A. 1891. De hymnis orphicis capitula quinque. Marburg.

- 1893. Nekyia: Beiträge zur Erklärung der Neuentdeckten Petrusapokalypse. Leipzig.

Dodds, E. R. 1951. The Greeks and the Irrational. Berkeley.

Festugière, A. J. 1936. "Comptes rendus bibliographiques: Guthrie (W.K.C.) Orpheus and Greek Religion." Rev. Ét. Grec.: 306-10.

Finamore, J. 1987. "The Orphic Labyrinth: The Orphic Poems by M. L. West." Helios 14: 59-63. 
Franz, G. 1836. "Epigrafe greca sopra lamina d'oro spettante al sig. Millingen." Bullettino dell'instituto di corrispondenza archeologica, 149-50.

Frazer, J. G. 1912. The Golden Bough: A Study in Magic and Religion, Part 5, vol. 1: Spirits of the Corn and of the Wild. 3rd ed. London.

Goettling, C. 1843. Narratio de oraculo Trophonii. Ienae.

Graf, F. 1993. "Dionysian and Orphic Eschatology: New Texts and Old Questions." In Faraone and Carpenter, eds., Masks of Dionysos, 239-58. Ithaca.

- 1996. "Orphic Literature." In Hornblower and Spawforth, eds., The Oxford Classical Dictionary, 3rd ed., 1078-79. Oxford.

Guthrie, W. K. C. 1952. Orpheus and Greek Religion. 2nd ed. London.

Harrison, J. 1922. Prolegomena to the Study of Greek Religion. Princeton.

Jeanmaire, H. 1939. Couroi et Couretes. Lille.

Johnston, S. I., and T. J. McNiven. 1996. "Dionysos and the Underworld in Toledo." MH 53: 25-34.

Kern, O. 1922. Orphicorum Fragmenta. Berlin.

Linforth, I. 1941. The Arts of Orpheus. Berkeley.

Lobeck, C. A. 1829. Aglaophamus. Darmstadt.

Macchioro, V. 1930. From Orpheus to Paul: A History of Orphism. New York.

Maury, L.-F. A. 1857. Histoire des religions de la Grèce antique. Paris.

Morford, M. P. O., and R. J. Lenardon. 1999. Classical Mythology. 6th edition. New York and London.

$\rightarrow$ Nilsson, M. 1935. "Early Orphism and Kindred Movements." Harvard Theological Review 28: 181-230.

Parker, R. 1983. Miasma: Pollution and Purity in Early Greek Religion. Oxford.

Redfield, J. 1991. "The Politics of Immortality." In Bourgeaud, ed., Orphisme et Orphée: En l'honneur de Jean Rudhardt. Recherches et rencontres 3: 103-17. Geneva.

Rohde, E. 1925. Psyche: The Cult of Souls and Belief in Immortality among the Greeks. Trans. W. B. Hillis. London.

Rose, H. J. 1936. “A Study of Pindar, Fragment 133 Bergk, 127 Bowra.” In C. Bailey et al., eds., Greek Poetry and Life: Essays presented to Gilbert Murray, 79-96. Oxford.

$\rightarrow$. 1943. "The Grief of Persephone." Harvard Theological Review 36: 247-50.

Sabbatucci, D. 1975. “Criteri per una valutazione scientifica del 'mistico-orfico' nella Magna Grecia." In Orfismo in Magna Grecia: Atti del quattordicesimo convegno di studi sulla Magna Grecia, 35-49. Napoli.

- 1979. Saggio sul misticismo greco. 2nd ed. Rome.

Scalera McClintock, G. 1995. "L'antica natura titanic. Variazioni sul mito greco della colpa." Filosofia e Teologia 9.2: 307-25.

Schmidt, J. 1884-1937. "Zagreus.” In W. H. Roscher, Ausfürliches Lexikon der griechischen und römischen Mythologie, vol. 6, col. 532-38. Leipzig and Berlin.

$\rightarrow$ Seaford, R. 1986. "Immortality, Salvation, and the Elements." HSCP 90: 1-26.

Smith, J. Z. 1990. Drudgery Divine: On the Comparison of Early Christianities and the Religions of Late Antiquity. Chicago.

Versnel, H. S. 1990-1993. Inconsistencies in Greek Religion. Vols. 1 and 2. Leiden.

Watmough, J. R. 1934. Orphism. Cambridge.

Welcker, S. G. 1860. Griechische Götterlehre. Göttingen.

West, M. L. 1983. The Orphic Poems. Oxford. 
Westerink, L. G. 1977. The Greek Commentaries on Plato's Phaedo. 2 vols. Amsterdam, Oxford, and New York.

Zeller, E. 1881. A History of Greek Philosophy. Trans. S. F. Alleyne from vol. 1, 4th ed., 1876. London.

Ziegler, K. 1894-1980. “Orphische Dichtung.” In Pauly-Wissowa, Realencyclopäde der classischen Altertumswissenschaft, cols. 1322-1417. Stuttgart.

Ziolkowski, J. M. 1997. "Introduction: The Making of Domenico Comparetti’s Vergil in the Middle Ages." In D. Comparetti, Vergil in the Middle Ages, trans. E. F. M. Benecke. Princeton.

Zuntz, G. 1971. Persephone: Three Essays on Religion and Thought in Magna Graecia. Oxford. 